\title{
Gene Technology and Gene Ecology of Infectious Diseases
}

\author{
Mae-Wan Ho ${ }^{1}$, Terje Traavik², Orjan Olsvik², Beatrix Tappeser ${ }^{3}$, C. Vyvyan Howard ${ }^{4}$, \\ Christine von Weizsacker ${ }^{5}$ and George C. McGavin 6
}

From the ${ }^{1}$ Biology Dept., Open University, Walton Hall, Milton Keynes, MK7 6AA, UK, ${ }^{2}$ Departments of Virology and Microbial Genetics, Institute of Medical Biology, University of Troms $\varnothing$, Norway, ${ }^{3}$ Institute for Applied Ecology, Postfach 6226, DE-79038 Freiburg, Germany, ${ }^{4}$ Foetal and Infant Toxipathology, University of Liverpool, Liverpool L69 3BX, UK, ${ }^{5}$ Postfach 130165, 53061 Bonn, Germany, ${ }^{6}$ Assistant Curator of Entomology, Museum of Natural History, Oxford University, Parks Road, Oxford OX1 3PW, UK.

Correspondence to: Mae-Wan Ho, Biology Dept., Open University, Walton Hall, Milton Keynes, MK7 6AA, UK.

Microbial Ecology in Health and Disease 1998; 10: 33-59

\begin{abstract}
According to the 1996 WHO Report, the world is heading for a major crisis in public health as outbreaks of new and re-emerging infectious diseases are striking at increasing frequencies within the past 10 to 15 years. The current strains of pathogens are moreover, resistant to known treatments; some strains being resistant to all or nearly all drugs and antibiotics. Horizontal gene transfer is now generally recognized to be responsible for the evolution of virulence and the spread of drug and antibiotic resistances. Many pathogens have crossed species barriers, having acquired genes from phylogenetically distant species that are involved in their ability to cause diseases. Recent findings document the extremely wide scope of horizontal gene transfer and the extensive recombination between genetic material from unrelated species that have contributed to the emergence of virulence and antibiotic resistances. The past 15 years coincide with the development of genetic engineering biotechnology on a commercial scale. Genetic engineering depends on designing vectors for cloning and transferring genes and involves artificially recombining and manipulating genes from unrelated species and their viral pathogens, thereby enhancing the probability for horizontal gene transfer and recombination. The urgent question which needs to be addressed is the extent to which genetic engineering biotechnology, by facilitating horizontal gene transfer and recombination, is contributing to the resurgence of infectious, drug-resistant diseases, and will continue to do so if allowed to proceed unchecked. An enquiry into the possible contribution of genetic engineering biotechnology to the etiology of infectious diseases is all the more pressing in the light of other relevant recent findings indicating that microorganisms genetically engineered for 'contained use' may not be effectively contained. Thus, biologically 'crippled' strains of bacteria can survive in the environment to exchange genes with other species; DNA released from cells is not readily broken down in the environment, thereby retaining the ability to transform organisms; some viral DNA can be more infectious than the virus itself; and routine chemical treatments for inactivating pathogenic microorganisms and viruses, before they are discharged into the environment, may be ineffective, leaving a substantial percentage of pathogens in an active infectious state. The combination of the different kinds of evidence is sufficiently compelling, especially in view of the precautionary principle, to warrant, at the very least, an independent public enquiry into genetic engineering biotechnology and the etiology of infectious diseases. Key words: horizontal gene transfer, virulence, antibiotic resistance, naked DNA.
\end{abstract}

\section{THE WORLD HEALTH CRISIS}

The world is heading for a public health crisis. At least 30 new diseases such as AIDS, ebola, several kinds of hepatitis and other deadly viruses have emerged over the past 20 years (see Table I) [compiled from WHO Report, 1996 (1), and other sources (2)], while old infectious diseases such as tuberculosis, cholera, malaria and diphtheria are coming back worldwide. Practically all the pathogens are resistant to drug treatment, many to multiple antibiotics. One third of the 52 million deaths from all causes in the world in 1995 were due to infectious diseases; over half of these in young children. The top killers were tuberculosis (3.1 million, mostly adults), malaria (2.1 million, including 1 million children), hepatitis B (1.1 million) and AIDS (more than 1 million). 'The optimism of a relatively few years ago that many of these diseases could easily be brought under control has led to a fatal complacency among the international community,' says the Director-General of WHO, Dr. Hiroshi Nakajima in a press release. Emerging diseases have become a major public health concern during the $1990 \mathrm{~s}$.

1.1 Have infectious diseases and drug resistance gone up recently?

Precise epidemiological data are not yet available, but the signs are that both the incidence and severity of outbreaks of multi-drug resistant pathogens may have experienced a sharp upturn within the past 10 to 15 years. For example, Salmonella infections have gone up 20-fold in some countries in Europe since 1980 (3). Similar increases are reported for haemorhagic E. coli 0157 food poisoning: 
between 1986 and 1996, the frequency of infection increased 10-fold in England and Wales, and 100-fold in Scotland (4).

The first widely used anti-malarial drug, chloroquine, came into use during world war II, and resistance did not appear until the early 1960s. By contrast, the new drug mefloquine, released in 1985, became useless in $60 \%$ of malaria cases within 5 years (5). Comparable accelerations in the development of antibiotic resistances have taken place in the same period. Antibiotics were introduced in the early 1940 s to treat infectious diseases, and resistance did not appear until the early 1950s (6). Resistance to penicillin, ampicillin and antipseudomonas penicillins in Staphyloccocus aureus went from almost $0 \%$ in 1952 to more than 95\% in 1992 (7). By the 1980s, S. aureus has also developed high levels of resistance to the synthetic penicillin, methicillin and all other $\beta$-lactams. The new fluoroquinolone antimicrobial, ciprofloxacin, was introduced in the mid-1980s, but resistance to it had reached more than $80 \%$ by 1992 . A study carried out by the Centers for Disease Control showed that ciprofloxacin resistance in $S$. aureus went from less than $5 \%$ to greater than $80 \%$ within one year (7).

By 1990, nearly every common pathogenic bacterial species had developed varying degrees of antibiotic resistance, often, multiple resistances. These include, besides Staphylococcus aureus (Toxic Shock Syndrome, postoperative infections), Streptococcus aureus (Toxic Shock-like Syndrome) S. pneumoniae (pneumonia) S. pyogenes (rheumatic fever) Haemophilus influenzae (mennigitis) $M y$ cobacterium leprae (leprosy), Neisseria gonorrhoeae (gonorrhea), Shigella dysenteriae (dysentry) and several other species of microbes that infect the human gut: E. coli, Klebsiella, Proteus, Salmonella, Serrratia marcescens, Pseudomonas, Enterococcus faecium, Enterobacteriaceae and Vibrio cholerae (cholera) (6). A strain of Staphylococcus isolated in Australia was resistant to 31 different drugs including cadmium, penicillin, kanamycin, neomycin, streptomycin, tetracycline and trimethyloprim (8). The various resistance capabilities were due to genes carried on different plasmids (independently replicating units of genetic material) that could be separately passed on from one bacterium to another. Two strains of $E$. coli isolated in a transplant ward outside Cambridge were resistant to 21 out of 22 common antibiotics: imipenen, as well as cefotaxime, ceftazdime, ciprofloxacin, gentamicin, ampicillin, azlocillin, coamoxiclav, timentin, cephalexin cefuroxime, cefotaxime, cefamandole, streptomycin, neomycin, kanamycin, tobramycin, trimethoprim, sulfamethoxazole, chloramphenicol and nitrofurantoin (9). These multi-resistant strains of bacteria are rapidly becoming totally invulnerable to treatment. Scientists in Japan have already isolated a strain of Staphylococcus aureus that is resistant even to the last resort antibiotic, vancomycin (10). Recent data showed that vancomycin resistance in Enterococci grew from 3\% in 1993 to $95 \%$ in 1997 in hospitals in San Francisco (11) In Italy, erythromycin resistance in Streptococcus increased 20-fold just between 1993 and 1995 (12).

\subsection{Factors contributing to the recent resurgence of infectious diseases}

The precise reasons for the resurgence of infectious diseases since the 1980s are not known. Many contributing factors have been suggested (1), among them,

- population growth combined with rapid urbanization,

- wars, civil turmoil and natural disasters,

- rapid increases in international air travel and the growing traffic in trade,

- expanding areas of human habitation and the consequent environmental destruction,

\section{Table I}

New diseases within the past 20 years (incomplete list)

1977: Legionella pneumophila, potentially fatal Legionnaires' disease

1977: Ebola virus, haemorrhagic fever-fatal in up to $80 \%$ of cases

1977: Hantaan virus, potentially fatal haemorrhagic fever with renal syndrome

1977: Campylobacter jejuni, diarrhoea

1980: Human T-lymphotropic virus I (HTLV-1), T-cell lymphoma-leukemia

1981: Staphylococcus aureus, bacteria, toxic shock syndrome

1982: Escherichia coli O157:H7 bacteria, bloody diarrhoea

1982: HTLV-2 virus, hairy cell leukaemia

1983: Helicobacter pylori, bacteria, peptic ulcer disease and stomach cancer

1983: Human immunodeficiency virus (HIV), AIDS

1985: Enterocytozoon bieneusi, parasite, persistent diarrhea

1986: Cyclospora cayetanensis, parasite, persistent diarrhea

1988: Hepatitis E virus, epidemics of jaundice in hot climates

1988: Human herpesvirus 6, fever and rash

1988: Salmonella typimurium, bacteria, diarrhea

1989: Hepatitis C virus, which causes liver cancer as well as liver disease

1989: Ehrlichia chafeensis, bacteria, infection

1991: Guanarito virus, Venezuelan haemorrhagic fever

1991: Encephalitozoon hellem, parasite, conjunctivities

1991: New species of Babesia, parasite, infection

1992: New strain Vibro cholerae O139, epidemic cholera

1992: Bartonella henselae, bacteria cat-scratch disease, bacillus angiomatosis

1993: Sin Nombre virus, adult respiratory distress syndrome

1993: Encephalitozoon cuniculi, parasite, disseminated disease

1994: Sabia virus, which causes Brazilian haemorrhagic fever

1994: Equine morbilivirus, respiratory illness

1995: Human herpesvirus 8, Kaposi's sarcoma in AIDS patients

1995: New monkey pox virus, human to human transmission, potentially fatal

1996: New rabies in Australia

1996: New hantavirus, human to human transmission 
- social changes including the clustering of young children in day-care centers and growing numbers of the elderly in nursing homes,

- complacency towards infectious disease in the public health sector and collapse of public health systems due to economic or social crises,

- the overuse and abuse of antibiotics in intensive farming and medicine.

One factor which has not yet been considered is genetic engineering biotechnology.

\subsection{Gene technology and gene ecology}

Gene ecology is an emerging discipline. It is prompted by recent findings that the genetic material-DNA or in some instances, RNA - can transfer horizontally from one organism to another through the external environment, instead of vertically by reproduction. Gene ecology is the totality of how genes function, mutate, move, transfer and recombine subject to feedback regulation from the interconnected levels of the genome, the physiology of the organism and the external ecological conditions.

Gene technology, or genetic engineering, can profoundly disturb the ecology of genes. The past 15-20 years witnessed the rise of genetic engineering biotechnology on a commercial scale. It is a technology for manipulating and transferring genes horizontally between species that do not normally interbreed. It is designed to break down species barriers and, increasingly, to overcome the species' defence mechanisms which degrade or inactivate foreign genes (13, 14).

For the purpose of manipulating, replicating and transferring genes, a range of artificial vectors have been constructed. Natural vectors for horizontal gene transfer comprise replicating, often mobile units of genetic material: viruses, plasmids and transposons. However, other pieces of DNA can also be taken up by cells and hence act as agent for horizontal gene transfer. While viruses consist of genetic material wrapped in a protein coat, plasmids and transposons are, to varying extent, naked DNA. Plasmids generally replicate in the cytoplasm, while transposons are integrated into the chromosome, but can move from one site to another in the same or different chromosome, or from chromosome to plasmid and vice versa. Plamids and transposons typically carry virulence genes and genes for antibiotic resistance.

Artificial vectors are made by joining together parts of the most infectious natural vectors in order to enhance horizontal gene transfer. The artificial vectors are 'crippled', which means that most, if not all of the genes causing disease and infectivity are removed. But it does not mean those functions cannot be supplied by, or regained from, other viruses and parasitic genetic agents that are always present in the environment and in the cells of all organisms. The gene to be transferred is as a rule inte- grated into the genetic material of the vector; viruses, however, can also transfer genes that are not integrated, but merely packaged within the protein coat.

To make a transgenic organism, the vector carrying the foreign gene to be transferred-transgene-is allowed to infect the cells of the organism. Once inside the cell, the vector can either multiply many copies of itself or become integrated into the genome of the cell. Most artificial vectors possess one or more antibiotic resistance marker genes, so transformed cells can be selected with the appropriate antibiotic(s).

There are three main routes for horizontal gene transfer: infection with viruses (transduction), through pieces of genetic material taken up into cell from the environment (transformation); or by unusual mating taking place between unrelated species (conjugation). As the entire orientation of genetic engineering is to facilitate horizontal gene transfer, it is to be expected that antibiotic resistance genes as well as virulence genes will inadvertently spread and recombine to generate new, drug and antibiotic resistant pathogens.

Indeed, the evolution of virulence and the spread of drug and antibiotic resistances are now linked to the extensive horizontal gene transfer and recombination events among bacteria and viruses, many of which may have occurred in recent years. For example, horizontal gene transfer and subsequent genetic recombination have given rise to the new bacterial strains responsible for the cholera outbreak in India in 1992 (15-17), and for the Streptococcus epidemic in Tayside in 1993 (18-21). The E. coli 0157:07 strain involved in the recent outbreaks in Scotland is believed to have originated from horizontal gene transfer from the pathogen, Shigella (22). Many unrelated bacterial pathogens, causing diseases from bubonic plague to tree blight, are now found to share an entire set of genes for invading cells, which have spread widely by horizontal gene transfer (23). Similarly, genes for antibiotic resistances have been transferred horizontally and have recombined with one another to generate multiple antibiotic resistances throughout the bacterial populations (24). Antibiotic resistance genes spread readily between human beings, and from bacteria inhabiting the gut of farm animals to those in human beings (25). Antibiotic resistant strains of pathogens have been endemic in many hospitals for years. In the USA, up to $60 \%$ of hospital-acquired infections are antibiotic resistant (1). A special form of multiple which confer resistance to a wide range of chemically unrelated drugs made its appearance among pathogens in the early 1990s (see Section 3.2), although it has been produced in $E$. coli in the laboratory since the 1980s (26).

Even more disturbing is the finding that antibiotics can increase the frequency of horizontal gene transfer 10 10000 -fold (27-30). Thus, antibiotics create the very conditions facilitating the spread of antibiotic resistance. The 
evolution and spread of antibiotic resistance predate genetic engineering, and are largely due to the profligate use of antibiotics in intensive farming, and in medicine (31, 32). However, the abuse of antibiotics per se does not account for the emergence of new viruses and new virulent strains of bacteria. Fifty new viruses have been identified just between 1988 and 1996 (33). The urgent question which needs to be addressed is the extent to which genetic engineering biotechnology, by facilitating horizontal gene transfer and recombination, is contributing to the resurgence of infectious, drug-resistant diseases, and will continue to do so if allowed to proceed unchecked.

This question is all the more important in the light of yet other recent findings indicating that microorganisms genetically engineered for 'contained use' may not be effectively contained, while our regulators are contemplating further relaxations of the guidelines on contained use ${ }^{1}$. Thus, biologically 'crippled' strains of bacteria have actually been found to survive in the environment to exchange genes with other species (reviewed in $(34,35)$ ). Naked viral DNA may be more infectious than the virus itself (36). DNA released from cells is not readily broken down in the environment, thereby retaining the ability to transform organisms (reviewed in $(34,37,38)$ ); and routine chemical treatments for inactivating pathogenic microorganisms and viruses, before they are discharged into the environment, may be ineffective, leaving a large percentage of pathogens in an active, infectious state (39). The combination of evidence is sufficiently compelling, especially in view of the precautionary principle, to warrant, at the very least, an independent public enquiry into the possible contributions of the industry to the etiology of infectious diseases.

This paper will review the following topics:

(a) The origins and nature of antibiotic resistance and its spread by horizontal gene transfer and recombination.

(b) The mechanisms and scope of horizontal gene transfer.

(c) The evolution of virulence and its spread by horizontal gene transfer.

(d) Genetic engineering and horizontal gene transfer.

(e) Other recent findings relevant to the possible contribution of genetic engineering biotechnology to the etiology of infectious diseases.

On account of the enormity of the subject areas, it is impossible for us to be exhaustive in our review. Our goal is to supply enough information for readers to judge for themselves whether the strength of the evidence together with the precautionary principle will justify the public enquiry proposed.

\section{ANTIBIOTICS AND EMERGING PATHOGENS}

When antibiotics were first introduced, microbial geneticists did not believe antibiotic resistance would pose any problems, based on the very low spontaneous mutation rates observed (24). Mutation-random changes in the genetic material - and selection - survival of the fittestwere thought, by most biologists, to sufficiently explain all characteristics of organisms. If the mutation rates are very low, then 'selection pressure' would have to be very strong for the character to spread.

Soon after antibiotics were used in medicine, it was discovered that livestock lived longer and grew faster when they were fed antibiotics to overcome infections. This led to 'prophylactic' treatments. In fact, antibiotics were routinely fed to promote growth, to chickens, cattle, pigs and dairy cows, which also extended the shelf-life of meat, poultry, eggs and dairy product. In the 1970s. it was discovered that chickens given high doses of antibiotics resulted in resistant Salmonella strains in both the meat and the eggs. By 1983, mutant strains of antibiotic resistant Salmonella that attacked human beings had emerged (6). The emergence of new pathogens is strongly associated with mutant strains that cross species barriers.

One of the clearest and most disturbing examples of mutant bacteria crossing from domestic animals to human beings, and of the transformation of a previously benign strain into a pathogen, is Escherichia coli, a common bacterium inhabiting the intestine of all human beings and many other mammalian species. Most of the time, E. coli is harmless, which is why it has been the major tool for genetic engineers, who have used it and its plasmids routinely to clone genes since the 1970 s (40). E. coli is the most intensively manipulated organism, and genes from species in every Kingdom have been transferred to and cloned in it. Perhaps it is not surprising that E. coli has emerged as a major pathogen.

The most prominent among pathogenic strains, E. coli 0157: H7, appeared in 1982, which, far from being benign, caused dangerous haemorrhages of the colon, bowel and kidneys of human beings; and it broke out suddenly and simultaneously in several states in the USA (41). Like most E. coli strains in the 1980 s, it was moderately resistant to the antibiotics ampicillin and tetracycline. Since then, many outbreaks have occurred all over the world, and in increasing frequencies. A mass outbreak in Japan in 1996 affected 10000, with 12 deaths in children. A series of outbreaks in Scotland in 1997 claimed 20 lives and made hundreds ill $(42,43)$.

Genetic fingerprinting - a technique that fragments the DNA using specific enzymes and reading the fragmentsbacks up epidemiological evidence that E. coli 0157:H7 arose recently; and up to 1993 , was endemic only to cattle in USA, Canada and Great Britain, and absent in cattle in the Far East (Thailand) (44). E. coli mutates fairly rapidly, hence the low degree of genetic variation observed among the 0157:H7 isolates before 1993 suggests they originated recently from a single clone. Most cases came from contaminated meat. However, outbreaks have also been asso- 
ciated with cheese, salami, raw vegetables, unpasteurized apple juice and water (45). The E. coli 0157, like other water-borne pathogens such as Cryptosporidium, Giardia and Shigella, had developed resistance to chlorine ((6), p.430). The mass outbreaks in Japan in 1996 were thought to be linked to white radishes (43), which may have come from contaminated soil. The specific toxicity of the strain is attributed to the Shiga-like toxin genes acquired by horizontal gene transfer from Shigella $(22,46)$. One of these genes, VT1, is almost completely identical in base sequence to that of Shigella, indicating again, that the gene transfer was a very recent event.

Studies of dozens of emergent species of pathogens showed that genes for antibiotic resistance and virulence often reside in the same regions of the bacterial DNA, in plasmids or transposons, which may be passed horizontally from one species to another, picking up extra genes, recombining and generating novel combinations in the process $(6,24)$.

\subsection{A profusion of mechanisms and genes for antibiotic resistance}

A profusion of biochemical mechanisms and genes are involved in antibiotic resistances, fully matching, if not surpassing the variety of targets at which antibiotics are aimed (7, 24, 46-48). Most antibiotics have a single primary target, usually a single step in the synthesis of macromolecules essential to the bacterial cell, and preferably do not affect their eukaryotic host cells. Thus several classes of antibiotics are aimed at different steps in synthesizing the bacterial cell wall. These include the penicillins or $\beta$-lactams, vancomycin and ristocetin, D-cycloserine, fosfomycin and bacitracin. Other classes of antibiotics are aimed at bacterial enzymes involved in the synthesis of DNA, RNA and proteins. These enzymes differ from their eukaryotic counterparts, although the effects of the antibiotics may not always be so selective, and are accompanied by varying degrees of toxicity for the eukaryotic host. Metronidazole, quinolones, nalidixic acid and novobiocin target DNA and DNA synthesis, while actinomycin and rifamycin inhibit transcription (RNA synthesis). Translation (protein synthesis) is targetted by a wide variety of antibiotics: streptomycin and other aminoglycosides such as kanamycin, neomycin, gentamicin, tobramycin, aikacin and netilmicin; tetracyclines, puromycin, chloramphenicol, erythromycin, lincomycin and clindamycin, and fusidic acid. In addition, antimetabolites such as sulfonamides and trimethoprim inhibit the synthesis of essential metabolites.

Resistances to every class of antibiotics have been identified (see Table II) [modified from (24)], the genes responsible may be found on the chromosome or in plasmids.

One of the commonest mechanism of resistance is the degradation or modification of the antibiotic by specific enzymes. Thus, the $\beta$-lactams are degraded by lactamases
Table II

A summary of mechanisms for antibiotic resistance

\begin{tabular}{|c|c|}
\hline Mechanism & Antibiotic \\
\hline \multirow{4}{*}{$\begin{array}{l}\text { 1. Modification of target to } \\
\text { reduce or eliminate } \\
\text { binding of antibiotic }\end{array}$} & $\beta$-lactams \\
\hline & Erythromycin \\
\hline & Lincomycin \\
\hline & Streptomycin \\
\hline \multicolumn{2}{|l|}{$\begin{array}{l}\text { 2. Inactivation of antibiotic } \\
\text { by enzyme }\end{array}$} \\
\hline \multirow[t]{2}{*}{ a. Hydrolysis } & $\beta$-lactams \\
\hline & Erythromycin \\
\hline \multirow[t]{4}{*}{ b. Derivatization } & Aminoglycosides \\
\hline & Chloramphenical \\
\hline & Fosfomycin \\
\hline & Lincomycin \\
\hline \multirow{2}{*}{$\begin{array}{l}\text { 3. Sequestration of antibiotic } \\
\text { by protein binding }\end{array}$} & $\beta$-lactams \\
\hline & Fusidic acid \\
\hline \multirow[t]{2}{*}{ 4. Metabolic bypass } & Sulfonamides \\
\hline & Trimethoprim \\
\hline $\begin{array}{l}\text { 5. Binding of antibiotic by } \\
\text { specific immunity protein }\end{array}$ & Bleomycin \\
\hline \multirow{2}{*}{$\begin{array}{l}\text { 6. Overproduction of } \\
\text { antibiotic target }\end{array}$} & Sulfonamides \\
\hline & Trimethoprim \\
\hline 7. Reduced uptake & Chloramphenicol \\
\hline \multirow[t]{3}{*}{ 8. Active efflux from cell } & Tetracycline \\
\hline & Chloramphenicol \\
\hline & $\begin{array}{l}\text { Multiple resistance to broad } \\
\text { ranges of antibiotics }\end{array}$ \\
\hline
\end{tabular}

all of which have arisen from one ancestral gene. On the other hand, aminoglycosides are inactivated by specific modifying enzymes encoded by 30 or more different genes, while chloramphenicol is inactivated by many acetyltransferases encoded by at least a dozen genes. Mutation of specific antibiotic target is also frequently involved in resistances. For example, streptomycin is overcome in Mycobacterium by mutations in the ribosomal RNA (rRNA) molecules required for protein synthesis, so that they have reduced affinity for streptomycin. Antibiotics may be inactivated simply by sequestration, or binding permanently to specific proteins. A metabolic bypass may appear to a reaction blocked by the antibiotic, or the inhibited protein may simply be overproduced by the bacteria in order to overcome the inhibition. Finally, resistance may be conferred by reduced uptake of the antibiotics or by increased rates of pumping them out of the cell-active efflux mechanisms.

Active efflux mechanisms are especially important for the multiple resistance to broad ranges of structurally unrelated antibiotics and drugs that have appeared in 
pathogenic bacteria within the past 10 years. These will be dealt with in Section 3.2.

Quite often, several biochemical mechanisms are involved in giving protection against a single antibiotic, resulting in a very high level of resistance. Cross resistances are also common within a class of antibiotics such as the aminoglycosides, so at least one kanamycin resistance gene used as a genetic marker has been found to confer cross-resistance to two new generation aminoglycosides, amikacin and tobramycin (49). A recently documented case of antibiotic cross resistance is even more serious. Enterococcus faecium inhabiting the gut of turkeys on farms using avoparcin as growth promoter are found to have developed cross-resistances to vancomycin and teicoplanin (50), the last defence against multidrug resistant Staphlococcus aureus.

Where do the genes conferring antibiotic resistances come from? And how do they manage to spread so quickly? Let us first address the question of the origin of the genes.

\section{ORIGINS OF ANTIBIOTIC RESISTANCE GENES}

\subsection{Biochemically specific mechanisms}

There are several sources of antibiotic resistance genes [reviewed by Davies (24)]. The first is from organisms producing the natural antibiotic, such as penicillin, which also produce the inactivating enzyme. As new $\beta$-lactams are introduced, the genes encoding the $\beta$-lactamases undergo mutational changes, often involving only one base substitution and a single amino-acid difference in the enzyme. That would be sufficient to enable the enzyme to recognize the new drug and to break it down. In this way, the enzyme extends its spectrum of resistances to new drugs. Numerous mutational variants of $\beta$-lactamase have already been identified, showing the ease with which appropriate mutational changes can arise in this gene. The variants derive from different genes which are themselves traced to a single ancestral gene. The versatility of the $\beta$-lactamase gene is such that when a series of inhibitors were made against the enzyme and used in combination with the $\beta$-lactam antibiotic - a kind of belt and braces approach-mutant enzymes arose, which not only break down the new antibiotic, but are, at the same time insensitive to the inhibitor.

More often, however, it is not at all clear where the antibiotic resistance genes come from. New genes seem to appear from nowhere. For example, the 30 or more genes involved in resistances to different aminoglycosides are not related to one another. Some are thought to have arisen from mutations of pre-existing genes encoding enzymes catalyzing normal metabolic reactions in the cell. Others may involve activation of previously 'cryptic' or hidden genes in the bacterial genome (see Section 3.2 below). Or they may have been acquired by gene transfer from another bacterium.

\subsection{Active efflux mechanisms}

Active efflux mechanisms are due to 20 or more genes in at least 4 gene families (see Table III) [modified from (47)], members of which can be found on plasmids or on the chromosomes. The genes code for transporter proteins situated across the cell membrane, that pump substances out of the cell, using ATP or protons as the source of energy. Recently, it has been shown that the genes for several efflux pumps are modulated in response to environmental conditions, and that many of the systems are also inducible by the substances to which they give resistance.

The chromosomally encoded efflux genes in $E$. coli belong to one or another of four inducible operons, $\operatorname{mar} R A B$, soxRS, emr $A B$ and acr $A B$ (reviewed in (26)). There is a great deal of homology among the genes comprising different operons. For example, the proteins encoded by the regulatory genes, $\operatorname{mar} R$ and $e m r R$ are two of the 15 proteins belonging to the MarR family, members of which are found, not only in Gram negative bacteria inhabiting the gut, but also in Gram positive bacteria, and the mycobacteria, including plant and animal pathogens, as well as free-living species.

One member of the MarR family, HpcR, found in soil-dwelling E. coli $\mathrm{C}$ strains, is a repressor of an operon encoding the enzymes that break down homoprotocatechuate $(\mathrm{Hpc})$, a phenolic compound derived from plants. The repressor protein, HpcR. binds to the operator and represses the synthesis of enzymes that breakdown Hpc when $\mathrm{Hpc}$ is absent. But when Hpc is present, the repressor protein binds to it instead, freeing the operator, so that transcription and synthesis of the enzymes can takes place. These observations suggest that naturally occurring noxious substances in the environment are the original inducers of the multiple antibiotic resistance operons.

Further observations in support of the idea are that other naturally occurring compounds, such as salicylic acid, dinitrophenol and naphtho-quionones, stimulate the expression of both soxS and $\operatorname{mar} R A B$. The natural naphthoquinolones, plumagin and menadine, are effective inducers at relatively low concentrations, and mutants lacking both the $\operatorname{mar} R A B$ and $\operatorname{sox} R S$ operons are notably hypersensitive to those compounds, while sensitivity to salicylic acid is only marginally affected. The $\operatorname{mar} R A B$ operon expression is enhanced at $30^{\circ} \mathrm{C}$ compared with $37^{\circ} \mathrm{C}$, as consistent with its origin in free-living bacteria (26). The multiple antibiotic resistance operons have, therefore, evolved from free-living bacteria. The enteric bacteria have simply reactivated or mutated the genes in the operons to allow them to cope with drugs and antibiotics. This class of mechanisms is reminiscent of the multidrug resistance which all mammalian and plant cells are able to develop in the presence of sublethal doses of noxious substances (see next Section). 


\section{Table III}

Examples of active efflux systems in bacteria

$\mathrm{CCCP}$, carbonyl cyanide m-chlorophenylhydrazone, SDS, sodium dodecylsulphate

\begin{tabular}{|c|c|c|}
\hline Transporter & Organism & Antibiotics \\
\hline \multicolumn{3}{|c|}{ 1a. Major facilitator in Gram-positive bacteria* } \\
\hline OtrB & Streptomyces rimosus & Oxytetracycline \\
\hline $\operatorname{Tet}(L)$ & $\begin{array}{l}\text { Bacillus subtilis } \\
\text { various cocci }\end{array}$ & Tetracycline \\
\hline Mmr & Streptomyces coelicolor & Methylenomycin \\
\hline ActII & S. coelicolor & Actinorhodin \\
\hline TcmA & Staphylococcus glaucescens & Tetracenomycin \\
\hline Nor A & Staphylococcus aureus & Fluroquinolones, basic dyes, puromycin chloramphenicol, tetraphenylphosphonium \\
\hline QacA & S. aureus & Quaternary ammonium compounds, basic dyes \\
\hline$B m r$ & B. subtilis & Basic dyes, chloramphenicol, puromycin, fluoroquinolones \\
\hline \multicolumn{3}{|c|}{ 1b. Major facilitator in Gram-negative bacteria* } \\
\hline TetA & E. coli & Tetracycline \\
\hline $\mathrm{CmlA}$ & Pseudomonus caeruginosa & Chloramphenicol \\
\hline$B c r$ & E. coli & Bicyclomycin \\
\hline$E m r B$ & E. coli & CCCP, nalidixic acid, tetrachlorosalicylanilide phenylmercury acetate \\
\hline EmrD & E. coli & CCCP, phenylmercury acetate \\
\hline \multicolumn{3}{|c|}{ 2. $R N D$ family } \\
\hline AcreE & E. coli & Basic dyes, SDS, erythromycin, novobiocin, fusidic acid, tetracycline, mitomycin $\mathrm{C}$ \\
\hline EnvD & E. coli & As above, plus others \\
\hline $\operatorname{MexB}$ & P. aeruginosa & Tetracycline, chloramphicol, fluroquinolones, $\beta$-lactams, pyoverdine \\
\hline \multicolumn{3}{|l|}{ 3. $S m r$ family } \\
\hline Smr & S. aureus & Quarternary ammonium compounds, basic dyes \\
\hline QacE & Klebsiella aerogenes & As above \\
\hline $\mathrm{MvrC}$ & E. coli & Methyltriphenylphosphonium, basic dyes. \\
\hline \multicolumn{3}{|c|}{ 4. $\mathrm{ABC}$ transporters } \\
\hline MsrA & Staphylococcus epidermidis & 14- and 15-membered macrolides \\
\hline $\operatorname{Dr} A, B$ & Streptomyces peucetius & Daunorubicin, doxoribucin \\
\hline $\operatorname{Tlr} C, B$ & Streptomyces fradiae & Tylosin \\
\hline
\end{tabular}

* Gram positive and negative bacteria are the traditional major divisions of bacteria. The Gram positive bacteria are surrounded by a thick peptidoglycan cell wall, which, however is permeable to small molecules; Gram negative bacteria, such as E. coli, are surrounded by a second membrane, which functions as an effective barrier to small molecules.

\section{4. 'RANDOM' VERSUS 'DIRECTED' MUTATIONS}

To measure the rate of 'spontaneous' mutations to antibiotic resistance in a bacterial strain, a small amount of a dilute suspension of bacteria is spread on a nutrient agarplate impregnated with a concentration of the antibiotic high enough to kill nonresistant bacteria, so that only those with a pre-existing mutation which happens to confer resistance will survive and form colonies. The spontaneous mutation rate for antibiotic resistance estimated in this way is typically $10^{-9}$ or lower, and is about the same for all other genes in the genome. This is the rate of random mutations, in other words, mutations that have no direct correlation to the environment, or the 'selective' regime. Based on these estimates, microbiologists did not believe that resistance to antibiotics would pose a problem when antibiotics first came into use (24). So why did antibiotic resistance evolve and spread so rapidly?
The usual explanation for antibiotic resistance, according to neo-Darwinian theory, is that it is due to the intense 'selection pressures' exerted by the antibiotics, so that even extremely low rates of spontaneous random mutations that happen to confer resistance to the antibiotic will be rapidly selected for, while those which do not happen to have the mutation will die out (see for example (32)). Antibiotic resistance has been assumed to be a classic case of the natural selection of random mutations. What actually happens is something else.

First of all, the mutations are not random in the sense that they pre-exist in the population, before exposure to antibiotics. All bacteria, with the exception of those that live in hot springs, are killed by boiling or cooking, which is therefore the surest way to prevent infection. They can also be killed by high enough concentrations of antiseptics or antibiotics to which they are susceptible. However, at 
lower concentrations of the noxious agent, the bacterium may fail to grow at first, but after some time, develop the required resistance to the drug which enables it to grow, multiply and form colonies. This ability to develop drug resistance is common to cells of all species-bacteria, fungi, plant and animal without exception (51-54). It is a physiological response shared by all the cells or organisms in the population, and is not due to selection of pre-existing random mutations. It is similar to the 'directed mutations' or 'adaptive mutations' (see Section 5 below), whereby starving, non-growing bacteria eventually acquire mutations that enable them to feed on new substrates (55-57). Secondly, competition is irrelevant among bacteria in the evolution of antibiotic resistance: they share their most valuable assets for survival-genes encoding resistance mechanisms against antibiotics - by passing them on horizontally between species.

In fact, the evolution of antibiotic resistance turns out to be a paradigm case of the 'fluid genome' in the new genetics, in which genes and genomes can mutate and undergo other changes when the ecological conditions call for them, and genes can even travel through the external environment from one organism to another $(35,58)$. We shall first consider 'adaptive mutations' in the broader context of the lessons which have been learned from molecular genetics within the past two decades.

\section{5. 'NATURAL' GENETIC ENGINEERING AND 'ADAPTIVE MUTATIONS'}

In a recent review, Shapiro (59) offers an appropriate perspective of bacterial evolution that sums up the recent discoveries of molecular genetics on how genomes are organized, on the biochemical mechanisms of genetic change and the cellular control networks regulating genetic change.

Bacterial genomes are organized in modular fashion at successive levels of a genetic hierarchy. At the lowest level of the hierarchy are genes composed of different domains (or subunits) that are reshuffled and recombined to give different genes. Different combinations of similar genes give rise to multigene units or operons, and different combinations of operons make up larger units or 'regulons' for complex functions such as chemotaxis, symbiosis and protein secretion. Regulons may coincide with independently replicating 'replicons', such as plasmids and viruses, each with its own signal for replication (origin of replication). Thus, mosaicism, or cut-and-splice genetic recombination is involved in every level of genome organization, and plays a key role in generating genetic diversity rapidly. But these mechanisms are by no means random.

Bacteria may have 'little tolerance for purely random variability' (59). Bacterial cells possess a wide range of repair and proof-reading functions to remove accidental change to DNA sequences and correct errors resulting from physiological insults. But the same cells also possess numerous biochemical mechanisms for changing and reorganizing DNA, suggesting that such changes are the result of the 'natural genetic engineering' ability of bacteria to respond to environmental challenges.

The possibility of 'natural' genetic engineering mechanisms responding to the environment gained considerable support in the discovery of 'adaptive mutation', in which starving bacteria acquire the appropriate genetic mutation enabling them to metabolize a new substrate, when the substrate is present in the 'selective' medium. A wide variety of mechanisms are involved in generating adaptive mutations, including point mutations (single base changes), deletions or insertions of nucleotides, conversions of gene sequences from one to another, site-specific integration of genetic material, DNA rearrangement and transposition (gene jumping) [reviewed in (59)].

There is much current debate as to whether those mutations are specifically 'directed' by the environmental challenge, or simply the consequence of a hyper-mutable state of stressed cells that generates many mutations indiscriminately at a high rate, increasing the chances of a lucky hit. In either case, however, it means that genes and genomes change as the result of built-in mechanisms that are subject to metabolic and environmental feedback regulation (57). As Shapiro points out, the ability to activate those mechanisms under stress can significantly accelerate evolutionary change in crisis without threatening genetic stability under ordinary circumstances. He surmises that further studies of mobile genetic elements and DNA rearrangements will ultimately uncover truly directed mutations. Just as signaltransduction systems of the cell can direct the transcriptional apparatus to specific locations in the genome to activate those genes, so it is possible that the mutational apparatus(es) can be similarly directed to mutate specific genes.

Shapiro regards the evolution of antibiotic resistance and virulence as clear examples of 'natural' genetic engineering mechanisms at work, and goes no further than that. This can easily lead human genetic engineers to justify what they do on grounds that bacteria themselves have been at it, probably for hundreds of millions of years. That kind of reasoning is fallacious and dangerous. As recent studies indicate, 'normal circumstances' for the vast majority of microbes in the environment as well as in our bodies may be a non-proliferating but metabolically active, non-virulent state $(60,61)$. This state is associated with layers of extracellular matrices or 'biofilms' in which typically mixed communities of microbes are embedded, where they enjoy a cooperative, multicellular existence rather like the cells and tissues in our body [see Ho (35), Chapter 14].

Furthermore, there is nothing 'natural' about the 'manmade' environmental conditions that have provoked microbes to engineer their genes and genomes. The discharge of toxic wastes, the destruction of the environment, and 
the overuse and abuse of antibiotics, have already thrown the 'natural' ecology of microbes seriously out of balance. And over the past 20 years, the extensive manipulation of genes and genomes by human genetic engineers is very likely to have exacerbated the situation. The ecology of microbes consists, not only of the usually understood interrelationships with other organisms, but also of genes within the genome, of the genome within the physiological state of the cell and the organism, which is in constant intercommunication with the external environment. Disease, we are told, cannot be understood apart from the ecological context (62). More importantly, it must be understood in terms of the nested levels in the ecology of genes (36) and microbes, which is inextricably entangled with the ecology of human beings.

\section{HORIZONTAL GENE TRANSFER}

The major role of horizontal gene transfer in spreading antibiotic resistance has only been recognized since the late 1980s, when a Conference on Antibiotic Resistance was co-sponsored by the Environment Protection Agency and the National Science Foundation of the USA to look into the mechanisms and factors affecting such gene transfer (63). The first definitive evidence for horizontal gene transfer came from DNA sequence analysis of the genes for neomycin-kanamyin resistance from Staphylococcus aureus, Streptococci and Campylobacter sp. (64) which were found to be essentially identical. Identity of sequence not only gives evidence for horizontal gene transfer, but also indicates that the transfer is a very recent event. Further evidence of horizontal gene transfer was subsequently obtained for a wide range of antibiotic resistances, by DNA sequencing or other methods of characterizing DNA (6570).

\subsection{The scope of horizontal gene transfer}

The scope of horizontal gene transfer is essentially the entire biosphere $(13,14,36,38,71-77)$. Genes are found to have been transferred, not only among microorganisms and viruses, but among eukaryote species and across traditional Kingdoms of organisms. Among eukaryotes, the main transfers have involved transposable elements (36, 77) such as the $P$ element among Drosophilids, and transposable introns among lower eukaryotes and bacteria (36). Some especially promiscuous elements such as mariner have been found in arthropods and vertebrates, including primates and humans, where it is associated with a neurological wasting disease (78). Gene transfer mediated by transposable elements do not require DNA base sequence homologies.

Transfers have occurred from bacteria to higher plants and vice versa. The best known example is the direct demonstration of transfer between the soil bacterium, Agrobacterium and plants. In a process bearing a strong resemblance to conjugation between bacteria (see Section 7.3), the tumour ( $T$ ) segment of the tumour-inducing ( $T i$ ) bacterial plasmid is transferred and incorporated into the plant genome $(79,80)$. However, it must be noted that nearly all cases of directly demonstrated horizontal gene transfer, especially those involving phylogenetically distant species, made use of already modified hybrid shuttle vectors that can transfer between species and replicate in both. These shuttle vectors possess signals for replication (origins of replication) in more than one species as well as the signal for DNA transfer (origin of transfer), and are hence much more likely to be successful in horizontal transfer than unmodified plasmids found naturally. The $T i$ plasmid is, indeed, the basis of a gene transfer vector system widely used for genetically engineering crop-plants (see Table IV).

Cross-Kingdom horizontal gene transfer by conjugation has also been demonstrated between bacteria and yeast using shuttle vectors derived from broad host-range promiscuous plasmids (see Section 7.3) which are already transferable between many bacterial species $(71,74,81)$. Such vectors can even substitute for the $T i$ plasmid in transferring genes from Agrobacterium to plants (82). Recent evidence documented the direct transfer of transgenes and marker genes from transgenic plants to soil fungi (83) and soil bacteria (84), indicating that secondary, unintended gene transfers can occur from genetically engineered crop-plants which are now released commercially into the environment. Despite the title of their publication, Schlutter et al. (84) actually observed a high 'optimal' gene transfer frequency of $6.2 \times 10^{-2}$ in the laboratory, from which they 'calculated' a frequency of $2.0 \times 10^{-17}$ under extrapolated 'natural conditions'. The natural conditions, are of course, largely unknown (36). In a recent Workshop at the German Environmental Protection Agency, two research groups reported secondary transfer of antibiotic resistance marker genes from transgenic plants to soil microorganisms $(85,86)$. Debris and exudates from transgenic plants will, therefore, be expected to transform bacteria and other microorganisms in the soil. E. coli cells have been successfully transformed by T-DNA, simply using total DNA from a transgenic plant; and the T-DNA vector was recovered as a circular plasmid in the transformed cells (79). In addition, other vectors such as viruses, insects and nematodes can also mediate unintended, secondary horizontal gene transfer (36).

Mammalian cells are known to take up foreign genes by a number of mechanisms including anastomosis, endosymbiosis, phagocytosis $(87,88)$ and also endocytosis, a process dependent on specific cell-membrane receptors binding to DNA or to macromolecules (most frequently proteins) complexed to DNA, so that the DNA can be internalized (36). It has even been suspected that gene transfer from bacteria to animal cells can occur by conjugation, a mating process previously thought to be confined to bacterial cells 
(see Section 11.3). The ability of certain viruses (retroviruses) to capture and transfer genes among mammalian cells is well-known and is associated with many animal cancers (see entries in (89)). Numerous illegitimate recombinations requiring no sequence homologies are due to retroviral insertion into the genome transferring genes horizontally between individuals of the same or different species (36). In short, a given gene from any organism has the potential to spread to all other organisms in the biosphere $(13,14)$.

However, DNA uptake by itself is not sufficient for successful gene transfer. Important barriers operate after the uptake of foreign DNA which break down, or otherwise block the integration, use and maintenance of the foreign genes $(40,77)$. Plasmid DNA requires an origin of replication that is recognized and used by the host cell before it can be replicated and maintained. Similarly, promoter sequences which can be recognized by the host are necessary for expressing the viral genes that make the virus, as well as expressing any other foreign genes carried by the virus. (Though, of course, origin of replication and promoter sequences can be acquired by recombination.) However, degraded DNA coding for parts or domains of proteins, or short regulatory motifs that bind transcription factors or otherwise enhance or repress gene expression may also be integrated, with significant genetic effects including cancer (36). Recombination of domains is already known to be a major factor in generating new proteins (59).

While the host cell DNA has its own origins of replication, methylation patterns (chemical markers) and promoter sequences which are specific to the species, artificial gene transfer vectors and other manipulated DNA have recombined origins of replication and promoter sequences from different species which can be recognized by different host species. In addition, they are designed to overcome the restriction systems which break down and 'silence' foreign DNA. Thus, genetic engineering may have created new avenues and possibilities for increasing the scope of horizontal gene transfer. We shall consider this in more detail in Section 10.

The scope of horizontal gene transfer among bacterial species has to be appreciated in the light of the revised phylogeny of the living world based on comparing ribosomal RNA (rRNA) sequences, a procedure first proposed by Carl Woese (90). Ribosomal RNAs are the most conservative molecules in evolution, and have not been subject to horizontal transfer between species. For these reasons, phylogenies based on rRNA sequences are generally considered to be the most reliable.

Comparisons of rRNA and other conserved sequences give a universal phylogenetic tree (Fig. 1) (91), revealing the true phylogenetic status of bacterial species. The tree is tripartite, with Bacteria (Eubacteria), Archaea (Archebacteria) and Eucarya (Eukaryotes) forming three more or less equal Domains. The traditional Kingdoms - Plants, Animals and Fungi (Coprinus) — are but twigs on a small peripheral branch of the Eucarya Domain, each twig having the same phylogenetic status as traditional Orders of bacteria. Within the Bacteria Domain, E. coli (a Gramnegative bacterium) is as distant from the Gram-positive bacteria, Bacillus, or Heliobacterium, as Homo sapiens is from the single-celled ciliate, Paramecium.

But even the revised phylogeny of the living world greatly underestimates the genetic diversity of Bacteria. The known bacterial species are less than $1 \%$ of all species that exist, as more than $99 \%$ cannot be cultivated in the laboratory by routine techniques (91). This highlights the dangers of releasing genetically engineered microorganisms or DNA into the environment.

All known pathogens belong to the Bacteria and some to the Eucarya Domain. None belongs to Archaea despite the fact that some archaean species share our environment and are part of our normal bowel flora. Strauss and Falkow (92) suggest there may be more fundamental differences between organisms that can become pathogens and those that do not. Another reason, however, may be that, until fairly recently, archaean organisms have not been genetically manipulated to the same extent as have bacterial species. Will the current trend towards increasing manipulation of archaean species also turn previously benign organisms into pathogens? Judging from the recent history of genetic engineering, it may only take a few years of intensive genetic manipulation of new (archaean) species for new pathogens to emerge. There are essentially no barriers left to horizontal gene transfer and recombination, particularly as the result of genetic engineering.

\section{MECHANISMS OF HORIZONTAL GENE TRANSFER}

There are three main mechanisms for gene transfer in bacteria, 1) by direct uptake of DNA (transformation) 2) through genes being carried by viruses that infect bacterial cells (transduction) and 3) through a mating process requiring cell to cell contact (conjugation). These processes have been studied most extensively in E. coli, although it is becoming clear that what is true for $E$. coli does not necessarily apply to other species. The scope of our present ignorance is enormous, but what is known already gives us serious cause for concern.

\subsection{Transformation frequencies are high}

Transformation among microbes in the environment has been extensively reviewed recently (36-38), showing that it is extremely widespread. The process involves DNA being released into the environment, its binding to the surface of bacteria, entry into the cell and recombination with the bacterial chromosome, or in the case of plasmids, reconstituting the plasmid. All these stages are facilitated by 


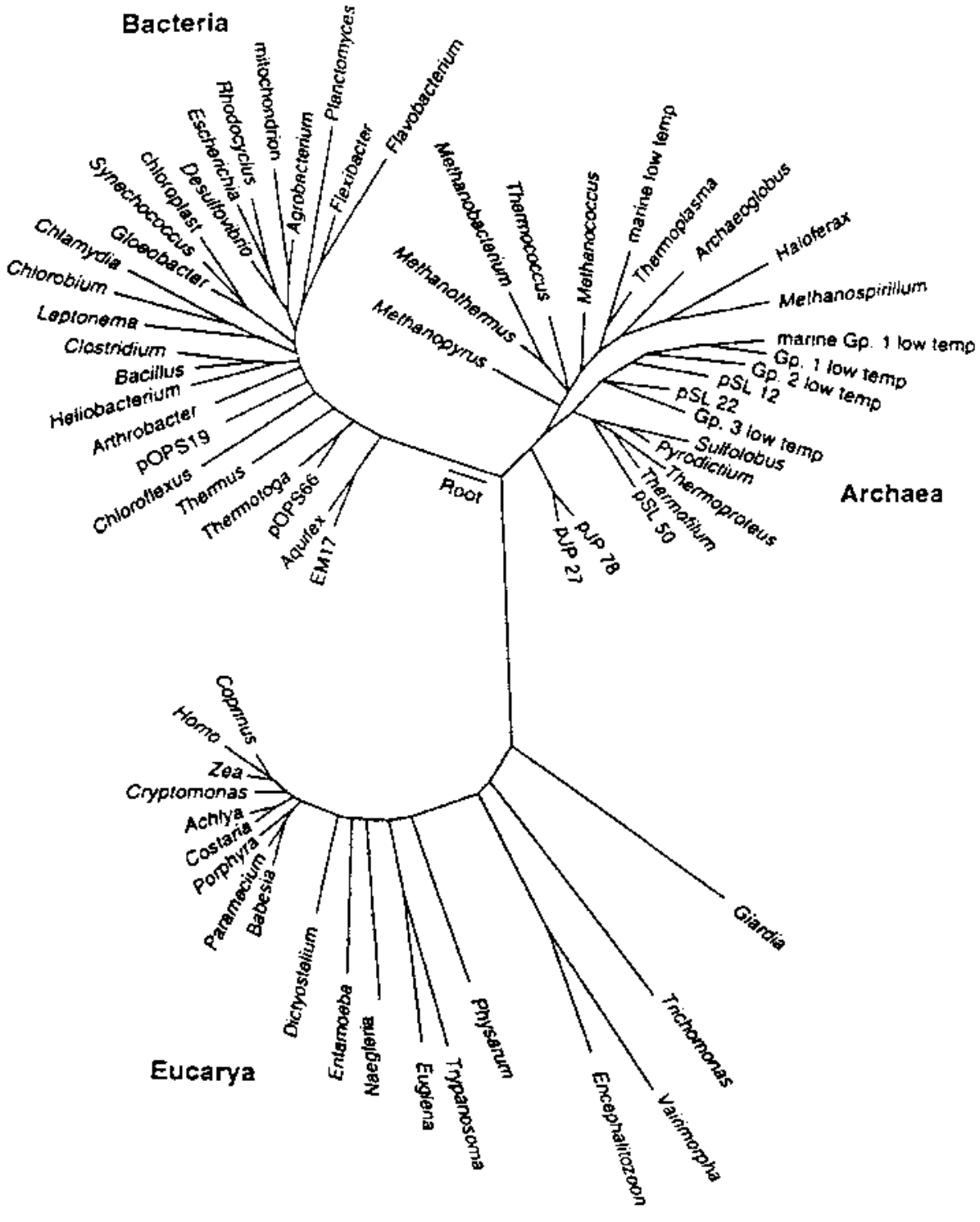

Fig. 1. The universal phylogenetic tree of the living world. bacterial proteins. Both chromosomal and plasmid DNA are able to transform bacteria, the frequency of transformation varying with the physiological state of the cell, diffusible factors excreted from the bacteria and the presence of salts in the environment. In addition, the nature of the DNA, its source, size, and state may also be important. Generally, transformation is most frequent if the DNA is from the same species, as its successful integration into the recipient genome depends on the degree of homology, i.e. the similarity in base sequence between the transforming DNA and the host DNA. It also depends on the DNA being resistant to the restriction enzymes in the host cell which break down foreign DNA. In one experiment, brief heat treatment $\left(9 \mathrm{~min}\right.$ at $\left.48.5^{\circ} \mathrm{C}\right)$ dramatically increased the competence of cells for receiving foreign DNA by 4 orders of magnitude (73). This was attributed to the heat inactivation of restriction enzymes, thereby increasing the success of gene transfer. Cross species, cross-genera and even cross-order transfers have been observed with chromosomal DNA. Plasmid DNA, in particular, has effected cross-Kingdom transformations among Eubacteria, Proteobacteria and Cyanobacteria (37).

DNA is not only released into the environment when the cells die, but is actively excreted by living cells during growth. Some species export DNA wrapped in membranebound vesicles. The DNA in a culture slime can be more than $40 \%$ of the dry weight. Thus, the environment is extremely rich in DNA. Marine water contains between 0.2 to $44 \mu \mathrm{g}$ per liter, and fresh water contains between 0.5 to $7.8 \mu \mathrm{g}$ per liter; while freshwater sediment has an upper concentration of $1 \mu \mathrm{g}$ per gram. Although enzymes breaking down DNA (deoxyribonucleases, DNases) are found in the environment, DNA is protected from degradation by adsorbing to detritis, humic acid, and in particular, clay 
and sand particles. Adsorbed DNA is equally efficient in transforming cells. Thus, the half-lives of DNA in soil is $9.1 \mathrm{~h}$ for loamy sand soil, $15.1 \mathrm{~h}$ for silty clay soil and 28.2 $\mathrm{h}$ for clay soil. While half-lives (time for half of the DNA to be broken down) in waste water are typically fractions of an hour, those in freshwater and marine water are 3 to $5 \mathrm{~h}$, with high values of 45 to $83 \mathrm{~h}$ on the ocean surface, and extremely high values of 140 and $235 \mathrm{~h}$ for the marine sediment (37). Adsorption of DNA to solid particles is a very rapid process, which means that DNA released into the environment can survive indefinitely and maintain its potential to transform other organisms. Transformation may be a major route of horizontal gene transfer: frequencies obtained under different environmental conditions, using artificial vectors and markers are found to be generally quite high, many ranging between $10^{-2}$ to $10^{-5}$ transformant per viable cell. In fact, transformation frequencies are often higher under natural conditions than in the laboratory. In a recent study in soil microcosms, activity due to earthworms was found to significantly enhance gene transfer between spatially separated bacterial species innoculated into the soil (93). A special form of bidirectional transformation by cell contact and fusion is now known to be widespread (38).

The release, or escape of naked recombinant DNA into the environment is a growing ecological problem, not only in the form of transgenic organisms, but also in vaccines, gene therapy vectors, and antisense oligonucleotide-short sequences of RNA complementary to the base sequence in the transcript of the genes - and ribozymes-RNA that act as enzymes to splice out intron sequences from transcribed genes - used in various forms of gene therapy (36). As mentioned earlier, even short sequences can have significant genetic effects when integrated into the genome of organisms for which they are not intended. The hazard of naked DNA is highlighted by the discovery that some viral DNA may infect non-permissive hosts for which the virus itself is noninfective (36). Intravenous injection of naked, circular polyoma viral DNA into rabbits and mice gave a powerful genetic expression with the development of antibodies and the production of new virus particles (94), whereas the native virus had no effect. Similarly, intravenous injections of recombinant plasmids in liposomes gave gene expression in several organs including the ovaries, indicating the possibility of an inherited genetic change (36). These findings are the basis for developing many recombinant DNA vaccines (95), for which ecological risk assessment has hardly even been considered.

DNA vaccines are inherently dangerous due to their ability to infect non-permissive hosts, thus crossing wide species barriers, with many opportunities for recombination to generate new viruses. Recombinant DNA vaccines are worse, as even small modifications of a virus can result in significant, unpredictable changes in its host range and virulence (36). In addition, they are more prone to recom- bine with other viruses to generate new viruses. Similar hazards are associated with the gene therapy vectors which are currently being developed (see also Section 11.3).

\subsection{Transduction is substantial in aquatic environments}

Transduction takes place by means of bacteriophages which are usually host specific, and are hence not expected to transfer genes between unrelated species. However, promiscuous phages with broad host ranges are capable of transducing genes between unrelated species (38). A bacteriophage consists of viral DNA wrapped in a protein coat, which binds to specific receptor sites on the bacteria. Once bound to the receptor sites, the bacteriophage injects its DNA into the bacterium. The internalized phage DNA either directs the synthesis of many bacteriophages which eventually break open (lyse) the cell, or the phage DNA may insert itself into the bacterial chromosome (as provirus or prophage) to become replicated with the chromosome. The bacteriophage can transfer genes by mispackaging a piece of bacterial DNA in the viral protein coat, or by packaging a viral DNA that has a piece of bacterial DNA incorporated into it. When such a virus infects a second cell, the bacterial DNA is transferred and may then become integrated into the new bacterial chromosome. The transducing phage may serve as a vehicle for a transposon that can then establish itself in an unrelated host, even though the phage DNA cannot do so, and hence contribute to cross-species, cross-genera gene transfer. Also, bacteriophages themselves evolve by horizontal gene transfer and recombination, leading to broadening of their host ranges (96). One study (97) found as many as 108 bacteriophages per milliliter in aquatic environments, so that onethird of the total bacterial populations is subjected to a phage attack every $24 \mathrm{~h}$, each capable of transducing foreign genes into the cell. Recently, Miller (98) reports 1011 virus particles per milliliter in fresh and marine waters.

Phages are now known to be intimately involved in the horizontal transfer of entire blocks of virulence genes into the bacterial chromosome, turning a previously benign strain into a pathogen in a single step. Co-integrates of phage and plasmids are also involved in the trafficking of blocks of virulence genes (see Section 9.1).

\subsection{Conjugation is essentially promiscuous}

Conjugation was previously thought to be a species-specific process requiring complex, complementary interactions between the genetic 'donor' and the genetic 'recipient'. Conjugation depends on certain conjugative plasmids, extrachromosomal pieces of DNA that are replicated independently of the chromosome. They carry genes required for the process of conjugation. These plasmids fall into different incompatibility groups. Ippen-Ihler and Skurray (99) listed seven or more incompatibility groups of over a hundred known plasmids, most of them carrying 
one or more antibiotic resistance genes. Plasmids in the same incompatibility group cannot be maintained in the same bacterial cell at the same time. However, there are common mechanisms for gene transfer that are interchangeable. One of these codes for the pilus, a tube-like structure connecting the donor with recipient cells in conjugation, through which plasmid DNA passes from the donor to the recipient. In other cases, such as the genes involved in the transfer of the plasmid, the gene products are specific to the plasmid and its host, and not interchangeable. Several of the incompatibility groups comprise 'promiscuous plasmids' with broad host ranges.

Conjugative plasmids can integrate themselves into the bacterial chromosome. In such cases, when conjugation takes place, the integrated plasmid will drag the bacterial chromosome with it across the conjugation tube from donor to recipient, leading to transfer of bacterial DNA as well as plasmid DNA. Donor DNA will then recombine with recipient DNA to generate new genetic recombinations. The DNA is thought to be passed in a single stranded form, which is resistant to breakdown by enzymes attacking double-stranded DNA (nucleases and restriction enzymes), thus ensuring a high success rate of gene transfer. The single-stranded DNA then directs the synthesis of the complementary strand to restore doublestranded DNA in both donor and recipient.

Recent studies indicate that conjugation has an extraordinarily wide host range, involving diverse, complex mechanisms that are not yet well understood (38, 100). 'Promiscuous' plasmids overcome species barriers, transferring genes promiscuously between phylogenetically distant species. At least several of the promiscuous conjugative plasmids have been exploited in constructing artificial shuttle vectors between $E$. coli and other distant species. One promiscuous conjugative plasmid is routinely used in Agrobacterium-mediated gene transfer to make transgenic plants (see Table IV). Shuttle vectors are essentially unstoppable, as they typically carry the origins of replication for both species as well as the origin of conjugative transfer. The strength of conjugative transfer is in the single-stranded DNA transferred directly, which escapes destruction by restriction enzymes. While the shuttle vectors are constructed to require 'helper' transfer functions provided by other plasmids, those plasmids can be present in the donor or recipient, or in a third species altogether. These 'tripartite' matings can easily occur in all environments, which are full of known and especially, unknown bacterial species.

In addition to conjugative plasmids, conjugative transposons mediate their own transfer to recipient cells during conjugation and insert into the recipient chromosome (101, 102). They can also jump from one site to another on the same chromosome, or from chromosome into plasmids and vice versa. These have also been exploited in constructing gene transfer vectors (see Table IV). A special class of such conjugative transposons, 'integrons' (103-105) are thought to be especially involved in the evolution of the multiresistance $\mathrm{R}$ plasmids within the past five decades (24). An integron carries its own gene encoding an enzyme, integrase, that catalyzes the site-specific integration of antibiotic resistant gene 'cassettes' within the integron, such that each inserted 'cassette' is provided with a ready-made promoter for expression. An integron can carry several cassettes, each encoding a different antibiotic resistance. The integron can facilitate recombination between cassettes to form exotic gene-fusions that code for multifunctional proteins. Integrons can also jump from the bacterial chromosome into plasmids and become transferred to another bacterium during conjugation.

During conjugation, genetic material not only goes from donor to recipient, but also in reverse, from recipient to donor, in a recently discovered process, retrotransfer (38).

\subsection{Effect of environmental pollutants on horizontal gene transfer}

Horizontal gene transfer is sensitive to many physical and chemical factors. In routine laboratory procedures for genetic transformation, heavy metals, singly or in combination, are used to greatly increase the competence of cells for transformation, as are enzymes such as muraminidases or proteases. Freezing and thawing, treatment with EDTA or other chelating agents, exposing cells to electric fields, or to DNA wrapped in liposomes (vesicles made from membrane lipids), are all effective in increasing the frequency of transformation. Yet, very few experimental investigations have been carried out into the effects of environmental pollutants on horizontal gene transfer. This is a glaring omission in view of the hundreds, if not thousands, of xenobiotics that currently circulate in our environment. And to which genetic engineering biotechnology is releasing, or discharging large volumes of agents - transgenic plants and animals, microorganisms, vectors, vaccines, and a range of naked DNA and oligonucleotides-all capable of taking part in horizontal gene transfer (36). We shall define xenobiotics as compounds released by human beings into the environment in concentrations that create harmful effects.

Xenobiotics can affect horizontal gene transfer in two ways (36). Some xenobiotics mutate DNA, thus influencing its uptake into cells. Kipling and Kearsey (106) have reported examples of minor changes in a DNA sequence which alter the host range of a transferable genetic element. Other xenobiotics can affect the cell membrane and/or intracellular functions thereby influencing the ability of cells to take up DNA, or to engage in conjugation and other forms of gene exchange.

As mentioned in the Introduction, antibiotics can increase horizontal gene transfer 10 to 10000 -fold. Antibiotics are heavily used in medicine and intensive agriculture, especially in fish farming, and constitute an 
important class of xenobiotics that already affect horizontal gene transfer significantly. It is known that ancestral antibiotic resistance genes have originated from antibioticproducing microorganisms themselves. The possibility has been suggested (24), therefore, that what we call antibiotics may actually be sex hormones for the bacteria, enhancing conjugation between cells. The process is naturally regulated by the product of the 'antibiotic resistance' gene, which shuts off the signal. Thus, the use of antibiotics not only leads to directed mutations of antibiotic resistance genes (see Section 5), it promotes the spread of those very genes among pathogens. The case for phasing out the use of antibiotics in intensive agriculture and fish farming is overwhelming. Antibiotics are also routinely used in genetic engineering biotechnology to select for transformed cells and recombinants.

The importance of synergistic interactions between xenobiotics is increasingly recognized. Recent research has shown that chemicals that are apparently harmless when tested singly, can have enhanced effects in mixtures at very low concentrations (107). As xenobiotics never occur singly in the environment, it is necessary to test drugs and chemicals in combination for realistic risk assessment. But this is a logistically and financially impossible task. To test just 1000 of the commonest toxic chemicals in combinations of three (at a standardized dosage) would require at least 166 million different experiments. An increasing number of scientists are calling for a drastic reduction in the number of chemicals to which we are exposed. They wish to see the introduction of reverse onus, in which a chemical must be regarded as potentially harmful until proven otherwise. Xenobiotics are not made by living organisms, possibly for the good reason that they are incompatible with healthy cellular activities. The synergistic effects of xenobiotics on horizontal gene transfer are, for the most part, unknown and unpredictable. The precautionary principle demands that we should strive to limit the release/escape of genetically engineered organisms, naked DNA and RNA sequences into the environment as much as possible.

\section{HORIZONTAL TRANSFER OF ANTIBIOTIC RESISTANCE GENES}

There could be very few barriers remaining to horizontal gene transfer. Antibiotic resistance genes, especially those carried on R (Resistance) plasmids and transposons, can in principle, cross species as well as genera and Kingdoms and even Domains. Evidence for transfer is obtained wherever and whenever it has been looked for, either by sequence analyses or by direct experimental investigations, as mentioned in Sections 1 and 6. We cite further examples below.

Tetracycline resistant genes are now found to be shared between many genera of bacteria, one of them, the TetL gene, is found in Actinomyces, Clostridium, Enterococcus,
Listeria, Peptostreptococcus, Streptococcus, Staphylococcus and Bacillus. Another gene, the TetK, is found in Bacillus, Clostridium, Enterocococcus, Eubacterium, Listeria, Peptostreptococcus, Staphylococcus and Streptococcus. (108110). More recently, both TetL and Tet $K$ have been found for the first time in soil bacterial species belonging to the genera Mycobacterium and Streptomyces, which can cause soft-tissue and skin infections (111). Antibiotic producing Streptomyces are believed to be the ancestral source of many aminoglycoside antibiotic resistance genes, but it is now gaining more of these genes back from the other species. These findings are of particular significance, as they 'suggest the potential for the spread of an antibiotic resistance gene into all environmental mycobacteria, including Mycobacterium leprae.'((111), p. 1411).

Even chromosomally encoded penicillin-resistance genes (penicillin-binding proteins, pbps, required for the uptake of penicillin) are readily transferred. Transfers of $p b p$ genes were found between Streptococcus pneumoniae and Neisseria gonorrhea which subsequently recombined to generate new hybrid genes (112).

\section{HORIZONTAL GENE TRANSFER AND THE EMERGENCE OF NEW AND OLD VIRULENT STRAINS}

The very same genetic mechanisms for horizontal gene transfer have been involved in the emergence of virulence among old and new pathogens since the mid 1980s. For example, there has been an increase since then, in sporadic cases of very severe invasive Streptococcus pyogenes infections in Europe, North America and elsewhere. In an analysis of 108 isolates from patients in the USA with Streptococal toxic-shock syndrome (113). A toxin frequently found is encoded by a gene, SpeA, belonging to a bacteriophage, which has become inserted into the bacterial genome. This gene has spread horizontally among different strains of $S$. pyogenes. In addition, genes encoding membrane surface proteins which determine binding properties and virulence of the bacteria, have also undergone numerous recombination events subsequent to horizontal gene transfer, giving rise to mosaic structures of the genes. This is superimposed on the accumulation of point mutations acquired as the result of interactions of the pathogens with the immunological system of the human host, which make antibodies against the membrane surface proteins of the bacteria. A similar picture emerged on analysis of group A streptococci isolated from a cluster of cases of serious infections over a 3-month period in Tayside, Scotland in 1993 (21). DNA sequence analysis of virulence factors suggests that they may have been recently acquired by horizontal gene transfer.

In the past, only Vibrio cholerae strains of the type $\mathrm{O} 1$ are known to have caused epidemcs, while non-O1 strains are associated with sporadic cases. However, the recent 
epidemic in Asia was caused by a non-O1 strain, Vibrio cholerae O139. It turns out that the new strain is identical to an earlier pandemic strain, O1 EL Tor, except for proteins involved in the capsule and the $\mathrm{O}$ antigen synthesis (which is used in typing the strains). This was due to the acquisition of DNA inserted into, and replacing part of the $\mathrm{O}$ antigen gene cluster. This suggests that $\mathrm{O} 139$ arose by horizontal gene transfer from a non-O1 strain into a type O1 strain (15-17).

Pathogenic mycoplasmas possess proteins called adhesins and related accessory proteins which are required for adhering to cells and subsequent disease development. Mycoplasma genitalium, implicated in urethritis, pneumonia, arthritis and AIDS progression, was found to encode one adhesin and 2 adhesin-related proteins that shared substantial sequence similarities, as well as genome organization, with those of another species, M. penumoniae (114). These were attributed to horizontal gene transfer events between the two species.

Most disturbing of all is the recent discovery that at least 10 unrelated bacterial pathogens, causing diseases from bubonic plague to tree blight, share an entire set of genes for invading host cells, which have spread by horizontal gene transfer, as they reside as a block, often in the bacterial chromosome, forming 'pathogenicity islands' (see Section 9.1) (23). More than 20 genes are involved in a system that secretes damaging proteins directly into host cells. They were first discovered in Yersinia, a genus of several species that cause human disease including bubonic plague and intestinal infections. At least some of the proteins are typical of eukaryotic cells, and are targeted at eukaryotic biochemistry (115), leading to the speculation that the genes were originally acquired from eukaryotic cells. We shall look at some of these systems in more detail later.

Like antibiotic resistance genes, many virulence genes reside on transposons or plasmids. For example, the ST-enterotoxin genes of E. coli are part of a transposon; while important virulence factors of Gram-negative pathogens (Shigella flexneri, Salmonella spp., Yersinia spp.) as well as Gram-positive pathogens (Clostridium tetani) are encoded in plasmids. Other factors, including the Shiga-like toxins of E. coli, the cholera toxin of Vibrio cholerae, diphtheria toxin of Corynebacterium diphtheriae, neurotoxins of Clostridium bolulinum and cytotoxin of Pseudomonas aeruginosa, are encoded by bacteriophage $(116,117)$. All these toxins and virulence factors obviously have the capacity to spread horizontally and to create new pathogens by recombination.

Virulence factors are often also located on the chromosome, where they form large blocks, which came to be called pathogenicity islands.

\subsection{Pathogenicity islands}

The term 'pathogenicity island' (Pai) refers to large chromosomal regions in pathogenic bacteria that encode virulence genes acquired by bacteria from unrelated organisms. Hacker et al. (118) reviewed the subject recently. They define a Pai according to the following criteria:

1. Carriage of (often many) virulence genes.

2. Presence in pathogenic strains, and absence or sporadic distribution in less-pathogenic strains of one species or a related species.

3. Different $\mathrm{G}+\mathrm{C}$ content in comparison to DNA of host bacteria, indicative of a foreign source.

4. Occupation of large chromosomal regions (often more than $30 \mathrm{~kb}$ ).

5. Represents compact, distinct genetic units, often flanked by direct repeats (like many viruses and transposons).

6. Association with tRNA genes and/or insertion sequence $(I S)$, a special class of mobile genetic elements, at their boundaries.

7. Presence of (often cryptic) mobility genes (IS elements, integrases, transposases, origins of plasmid replication).

8. Instability.

A bacterial pathogen may have one or more pathogenicity islands. For example, uropathogenic (causing infection of the urinary tract) E. coli strain 536 has two Pais: Pai I encodes only $\alpha$-haemolysin, responsible for haemolysis, while Pai II carries the $\alpha$-haemolysin gene, (hly), as well as the P-related fimbriae gene (prf) involved in attachment of the bacterium to the host cell. Pai I is flanked by the selC gene encoding the selenocysteine-specific tRNA and two direct 16 bp repeats, while Pai II is associated with leuX, which encodes a leucyl tRNA, and two direct $18 \mathrm{bp}$ repeats. The direct repeats in both cases are attachment sites for bacteriophages ( $\phi$ R73 in Pai I, and P4 in Pai II). Cryptic integrase genes of these phages are located near the respective tRNA genes. Thus, the Pais probably originate from integrated prophages which have picked up a range of virulence genes to turn them into pathogenicity islands. In addition, sequences homologous to the origins of replication of plasmids, parts of IS elements, and 'recombination hot spots' (sites which are most frequently involved in recombination) are also present. All these indicate that Pais are highly mosaic, and many recombination events have contributed to their evolution. Have some of these recombinations been inadvertently created by genetic engineering?

Phages, plasmids and pathogenicity islands are involved in rapid evolutionary changes of bacteria by 'quantum leaps'. Pais often exhibit features of both plasmids and phages, reflecting the formation of co-integrates of both types of extra-chromosomal elements. The acquisition of new genes following horizontal gene transfer results in the 
generation of new variants of pathogens. Drug-resistant strains of Mycobacterium tuberculosis and Streptococcus penumoniae, the new $V$. cholerae serotype 0139 , E. coli 0157, Haemophilus influenzae biotype aegypticus, are examples of such new types of pathogens generated by horizontal gene transfer.

Enteropathogenic bacterial strains (infecting the gastrointestinal tract), including E. coli $0157: \mathrm{H} 7$, have the ability to remodel the actin cytoskeleton of infected cells, producing so-called 'attaching and effacing' (AE) lesions in the host cell. A $35.4 \mathrm{~kb}$ pathogenicity island in enteropathic $E$. coli, called the locus of enterocyte effacement, (LEE), has been found to contain all the known genes necessary for AE lesions (119). Several features of the LEE suggest that it has been acquired recently by the enteropathogenic $E$. coli and other AE bacteria. These include, (i) a $\mathrm{G}+\mathrm{C}$ content of $38.4 \%$, compared with the $51 \%$ of the bacterial chromosome as a whole. (ii) the strict conservation of LEE base sequences within AE pathogens of 3 genera of bacteria, including the distantly related Hafnia alvei, and (iii) insertion within selC tRNA gene, the same site of insertion for paiI in uropathogenic E. coli and the bacteriophage $\phi \mathrm{R} 73$. The LEE is one among a whole class of genetic systems (type III systems) that are extremely sophisticated in exploiting host cell functions (see below).

\subsection{Exploitation of host cell functions by bacterial pathogens}

Recent studies reveal the common strategies used by a wide range of pathogenic bacteria as well as the unique tactics adopted by individual species in establishing infection. Many host cell functions are exploited by the pathogens, including signal transduction pathways and rearrangements of the cytoskeleton (115).

Adhesion to host cells is the first stage in disease development. Bacterial pathogens produce a range of proteins, adhesins, which mediate adhesion to host cells. These adhesins interact with surface membrane components of mammalian cell, many of which serve as receptors for the bacterial adhesins. The host cell is often an active participant in adhesion by synthesizing the receptors for adhesion. For example, enteropathogenic E. coli adheres to intestinal epithelial cell surfaces by destroying host microvilli and rearranging the cytoskeleton to form a pedestal on the host cell surface on which the bacterium resides (the $\mathrm{AE}$ lesions). To achieve this, the bacterium secretes at least two proteins, EspA and EspB, which activate host cells by inducing a series of events involved in signal transduction: calcium flux, inositol phosphate production, phosphorylation of the amino-acid tyrosine in a membrane protein, and finally, rearrangement of the cytoskeleton. The secretion of the proteins that activate epithelial cells is mediated by a specialized secretion system called the type III secretion system, version of which are being identified in an ever-increasing number of human, animal and plant pathogens. They allow the bacteria to attach to cells, to enter the cells, or to prevent themselves from being swallowed by phagocytic cells.

Type III secretion systems comprise at least 20 gene products which are essential for the virulence of these pathogens; the genes encode both secreted effector proteins and the machinery necessary for secretion and translocation into target cells. Enhanced secretion of the virulence factors often occurs after contact with host cell surfaces. Although the secreted virulence factors differ among pathogens which cause different diseases, the secretion machinery is often interchangeable. The same type III system is involved in invading cells by activating host signalling pathways, leading to appropriate changes in the cytoskeleton which internalize the pathogens. One type of internalization mechanism is shared by Yersinia and Listeria, while another is shared by Salmonella and Shigella. In Salmonella, the type III secretion system responsible for invading host cells forms a pathogenicity island on the chromosome, while in Shigella, the system is found in a large virulence plasmid.

In addition to invasion systems for entering epithelial cells, Yersinia species have evolved mechanisms to avoid uptake by phagocytic cells. The anti-phagocytosis strategy relies on the expression of Yop proteins, which also involves type III secretion systems. One protein, Yop E paralyzes the cellular cytoskeleton, while another, Yop $\mathrm{H}$ is a broad-spectrum tyrosine kinase that interrupts phosphotyrosine signaling associated with phagocytosis. Yet another protein, Yop $\mathrm{O}$, has homology to mammalian enzymes, serine and threonine kinases involved in signal transduction, and like Yop $\mathrm{H}$, is targetted to the inner surface of the host-cell plasma membrane.

Among Gram-positive bacteria, Listeria monocytogenes enters mammalian intestinal cells by means of a surface protein, internalin. Internalin contains multiple copies of a 22-amino acid leucine-rich tandem repeat (LRR), a feature of several eukaryotic proteins that are generally involved in protein-protein interactions. Another surface protein, InlB, belonging to the internalin multigene family and displaying similar LRRs, mediates entry into cultured hepatocytes, Hela cells and Chinese Hamster Ovarian cells.

Type III secretion systems have also been identified in the plant pathogens Ralstonia, Pseudomonas, Xanthomonas and Erwinia, and are involved in their ability to cause diseases (120).

\section{HAS HORIZONTAL GENE TRANSFER INCREASED RECENTLY?}

The evidence is now overwhelming that horizontal gene transfer has been responsible for both the rapid spread of antibiotic resistances and for the emergence of virulent strains of pathogens in recent years. Has horizontal gene transfer increased in scope and frequency since genetic engineering biotechnology began? 
In the Introduction, we have alluded to the apparently accelerated rates in the evolution of drug and antibiotic resistance and of new pathogens since the 1980s. Furthermore, sequence identity or near-identity in both virulence and antibiotic genes from unrelated species indicate that a high proportion of the horizontal gene transfers may be very recent.

A study carried out in 1983 on strains of bacteria isolated between 1917 to 1954 , at least ten years into the antibiotics era, but well before genetic engineering got underway, showed that none of the strains carried any antibiotic resistance (121). By contrast, it takes one to two years in the post-genetic engineering era for resistance to develop and spread, rendering new antibiotics useless in 4 years $(11,25)$. However, $24 \%$ of the strains from the pre-genetic engineering era encode genetic information for the transfer of DNA from one bacterium to another; and from at least $19 \%$ of the strains, conjugative plasmids carrying no antibiotic resistance were transferred to the laboratory strain E. coli K12 (121). Thus, while conjugative plasmids and other mechanisms for horizontal gene transfer may predate both the antibiotics and genetic engineering eras, their prevalence and the range of drugs to which they confer resistance have greatly increased, especially since genetic engineering got underway.

It would also be of interest to screen these strains from the pre-genetic engineering era for pathogenicity islands, which will contribute to our understanding of how pathogenicity islands have evolved since.

\subsection{Barriers to horizontal gene transfer}

The frequency of horizontal gene transfer may therefore be determined, not so much by the actual mechanisms that exist for mediating transfer as on the existence of barriers that act against the process $(77,122,123)$. In bacteria, a major mechanism for limiting horizontal gene transfer is restriction - the destruction, or inactivation of foreign DNA. There are 11 restriction/modification systems in enteric bacteria which fall into three families, $h s d R$, $h s d M$ and $h s d S$. The alleles (different variants) of the $h s d R$ family are responsible for destroying foreign DNA, while those of $h s d M$ and $h s d S$ families are responsible for methylating, thereby protecting DNA molecules that escape restriction and facilitating their recombination into the genome. A second barrier is the mismatch DNA repair system encoded by the mutL, mutS and mut $H$ genes of $E$. coli and $S$. typhimurium, which severely inhibits recombination of nonhomologous DNA. However, another genetic system, the error-prone SOS system, activated under stress, stimulates such recombination. In addition, as mentioned in Sections 6.1 and 7.3, there are origins of replication and origins of transfer specific to DNA from different species, so that even if DNA is transferred, they cannot be replicated and maintained, so that the chances of integration into the chromosome would also have been much reduced, unless, of course, the DNA has been manipulated to combine origins of replication from different species.

Another important influence on the frequency of horizontal gene transfer is the ecology of the microbes concerned, as mentioned in Section 5. Stressful conditions appear to reduce the effectiveness of restriction and to encourage recombination $(124,125)$. Starving bacteria are also more competent in taking up DNA from the environment, and hence to become transformed (126). And heat treatment greatly increases the frequency of transformation (Section 7.1); while the effects of xenobiotics in the environment on horizontal gene transfer, apart from antibiotics, remain largely unknown (see Section 7.4).

\subsection{Genetic engineering biotechnology breaks down species barriers}

One main contributing factor to the recent increase in the scope and frequency of horizontal gene transfer may be the deliberate acts of genetic engineers to break down species barriers. They do so by constructing a range of chimaeric vectors for cloning and transferring genes. These artificial vectors have the following important characteristics that enhance horizontal gene transfer.

- They are already derived from elements that mediate horizontal gene transfer most effectively.

- Their chimaeric nature means that they possess sequence homologies to DNA from widely different species and their viral pathogens, plasmids and transposons, thus facilitating successful horizontal transfer and recombination.

- They routinely contain antibiotic resistance marker genes enhancing their successful transfer in the presence of antibiotics, either intentionally applied or as xenobiotics in the environment.

- They often have origins of replication and transfer sequences (see Section 6.1), all of which facilitate horizontal gene transfer and recombination. In this context, the fact that they are 'crippled', so that genes for mobility and/or virulence are removed, is irrelevant, as helper functions can be supplied by other viruses, plasmids and mobile genetic elements present in the donor, recipient or a third strain of bacteria. And virulence genes can be regained by recombination.

- It is well-known that chimaeric plasmids and viral vectors are subject to structural instabilities which make them more prone to recombine (40). Vector instability is a continuing problem for genetic engineers and the biotech industry as far as the stability of the transferred genes is concerned. It also increases the probability and scope for unintended, secondary horizontal gene transfer, which has already been directly demonstrated (see Section 6.1).

- The now routine incorporation of strong promoters and enhancers in vectors to boost expression of transgenes is 
one main cause of structural instability, which is in addition to the instability arising from the attendant metabolic stress to the organism, that again, may increase unintended horizontal gene transfer (127).

- Finally, vectors are designed to escape restriction (128) thereby also enhancing the probability of successful horizontal gene transfer.

The construction of artificial vectors is fundamental to genetic engineering. Some examples of the vectors used are given in Table IV (compiled mainly from (40)). All classes of genetic elements that mediate horizontal gene transfer have been used in constructing vectors: plasmids, phages, transposons, plus a range of pathogenic plant and animal viruses. As stated in a standard textbook on genetic manipulation, 'Many animal viruses have been subjugated as vectors. Virtually every virus that has been studied in any detail and that has a DNA genome or a DNA stage in its replication cycle has been manipulated in this way' ((40), p. 225).

Although different classes of vectors are distinguishable on the basis of the main framework sequence, practically everyone of them is chimaeric. Important chimaeric vectors are the shuttle vectors which enable genes to be cloned (multiplied) in E. coli and transferred (transfected) into unrelated species in every Kingdom. Similarly, vectors used in manipulating plants and animals typically contain sequences from a range of plant and animal viral pathogens, as well as antibiotic resistance genes, often originating from promiscuous resistance plasmids and transposons. Phage vectors and phasmid vectors (hybrid of phage and plasmid) are also extensively used, and may have special relevance for the evolution of pathogenicity islands in bacterial pathogens (see Section 9.1).

Thus, genetic engineering biotechnology has effectively opened up highways for horizontal gene transfer and recombination, where previously, there was only restricted access through narrow, tortuous footpaths. These gene transfer highways connect species in every Domain and Kingdom with the microbial populations via the universal mixing vessel, E. coli. We review further circumstantial evidence that artificial gene transfer vectors increase the scope and frequency of horizontal gene transfer.

\subsection{Artificial gene transfer vectors increase horizontal gene transfer}

It is not easy to transfer genes successfully between species as we have already emphasized, there are barriers to horizontal gene transfers (see Section 10.1). That is why, apart from transposons which are promiscuous, such events were relatively rare in our evolutionary past. For example, analyses of 145 nonvertebrate globin gene sequences showed that there were probably two cases of horizontal gene transfer, one from the common ancestor of ciliates and the green algae to the ancestor of cyanobacte- ria and the other, from the ancestor of the yeasts to the ancestor of bacteria (129). Natural gene transfer vectorsviruses, plasmids and transposons - have probably always existed, especially in the microbial species; but they were to varying degrees host specific, so that the frequency of conjugal transfers are higher between the same species than with other species (130). Naturally isolated vectorseven those that carry antibiotic resistance genes and have therefore already undergone evolution by horizontal gene transfer - have not exhibited the same wide range of transfer capabilities.

Horizontal gene transfers have been directly demonstrated between bacteria in the marine environment (30, $131,132)$, in the freshwater environment (133), and in the soil (134). Again, in all the experiments, horizontal gene transfers were mediated by specially constructed hybrid plasmid vectors, of the sort used in genetic engineering. Horizontal gene transfer occurs preferentially in interfaces between air and water and in the sediment, and especially under nutrient depletion conditions (135), thus refuting the claim that nutrient-rich media are necessary to support horizontal gene transfer. Horizontal gene transfer of antibiotic resistances has even been demonstrated in wastewater treatment ponds, the effluent from which is increasingly being used for irrigation in developing countries (136). As pointed out in Section 7.1, frequencies of horizontal gene transfer may be greater under natural conditions than in the laboratory (93).

Horizontal gene transfer is not limited to the external environment. It has been demonstrated between gut bacteria in mice and chickens $(137,138)$ and in the gut $(139$, 140) as well as urogenital and respiratory tract of human beings (141).

Stephenson and Warnes (142) wrote,

'The threat of horizontal gene transfer from recombinant organisms to indigenous ones is...very real and mechanisms exist whereby, at least theoretically, any genetically engineered trait can be transferred to any prokaryotic organism and many eukaryotic ones' (p. 5).

A year later, another molecular geneticist, who works on transgenic plants, admitted that, '...the potential for horizontal (gene) transfer may be greater than thought previously' (143).

\section{BIOLOGICAL CONTAINMENT MAY BE INEFFECTIVE}

When Paul Berg and others (144) published their letter on 'Potential biohazards of recombinant DNA molecules' in Science, the main areas of concern were the possibilities of survival and spread of genetically engineered microorganisms (GEMs) and the dissemination of the new recombinant gene sequences to bacterial hosts throughout the different bacterial communities via horizontal gene trans- 
fer (34). To address those concerns and to comply with their own recommendations, general risk assessments were made on the survival and spread of GEMs and the stability of isolated DNA. However, those assessments were often based on little more than plausible assumptions and not on experimental results [see (34)]. One assumption was that because GEMs carried genetically engineered plasmids, they would not survive due to their extra burden of genetic information (145). Moreover, laboratory strains were 'biologically contained' due to crippling mutations, which meant that they required specific nutrients for survival. Consequently, the general perception was that even if the GEMs were accidentally released, they would not survive in the environment, and would therefore have no negative impacts. Similarly, released DNA would be rapidly degraded by DNAses in the environment and in the digestive tract, if ingested. These 'impact assessments' made it unnecessary to investigate the actual survivals of GEMS in the environment, and allowed genetic engineering biotechnology to proceed without extensive safety measures. The same arguments were later used to promote relaxation of the already lax safety guidelines. And further relaxations are now being contemplated (see Section 11.6).

It is clear that current 'risk assessment' is strongly based on assumptions rather than scientific data. These assumptions, furthermore, can be totally at odds with reality, as they are now revealed to be, which is why such risk assessments are a source of hazard in themselves. 'Risk' is technically the probability of a hazardous event multiplied by the hazard caused. If the hazard is great, even a 'very low probability' will give significant, unacceptable risk. This is a proper application of the precautionary principle. It is often claimed that the hazards are unknown. That is not so. We have identified at least some of the hazards in the spread of virulence, drug and antibiotic resistance in the recent resurgence of infectious diseases.

Our limited enquiry has led us to conclude that the original concerns of Paul Berg and other scientists on the hazards of genetic engineering may have been borne out by scientific evidence that has accumulated since: horizontal gene transfer (and recombination) is the greatest threat to public health facing us to-day, especially if commercial scale genetic engineering biotechnology is allowed to continue unchecked. We may only be seeing the tip of the iceberg, as far as the possible contribution of genetic engineering biotechnology to the etiology of infectious diseases is concerned. In this final Section, we shall review other relevant findings indicating that microorganisms genetically engineered for 'contained use' may not have been effectively contained.

\subsection{DNA can persist in the environment}

Genes carried by vectors as naked DNA as well as chromosomal DNA can survive indefinitely, especially when adsorbed to solid particles in all environment; on surfaces of water, as sediment, in the soil, where they are efficiently taken up by other microbes [reviewed by $(34,146)$ ] (see Section 7.1). Although DNA is rapidly broken down in waste water, adsorption to solid particles in the sludge, which happens very quickly, will stabilize it and prolong its transforming capacity. In addition, DNA is now found to persist for long periods in the laboratory clinging to many different surfaces. As already pointed out in Section 7.1, transformation by the uptake of DNA is a major route of horizontal gene transfer in the environment. DNA is not only released when cells die, but are actively secreted by living cells, and even fragments of genes can have significant effects when transferred (Section 7.1). As increasing amounts of recombinant DNA, especially of the 'naked' variety, are discharged into the environment, the risks associated with DNA transformation will rise exponentially.

\subsection{DNA can resist digestion in the gut}

Earlier studies supported the assumption that DNA is broken down into small fragments in the stomach and subsequently further degraded by nucleases in the digestive system. But more recently, Schubbert and coworkers (147), using the much more sensitive PCR (polymerase chain reaction) technique, were able to detect large fragments of the M13 phage DNA, which were fed to mice, in the faeces, the blood stream and within white blood cells. The persistence of DNA in the gastrointestinal tract suggests that transformation of gut bacteria may occur. This is very relevant to the spread of antibiotic resistance marker genes which are currently in nearly all commercially approved transgenic food crops.

Subsequent studies by the same group revealed that the DNA fed to mice was taken up, not only by white blood cells, but also by spleen and liver cells. The M13 phage DNA was reisolated from spleen cells and some were found to be attached to mouse DNA $(148,149)$, suggesting that it had become integrated. This raises general questions on the ability of gene transfer vectors to invade mammalian cells directly, and indeed, that has been known to occur.

\subsection{Invasion of mammalian cells by vector DNA and viral $D N A$}

Studies made since the 1970s have documented the ability of bacterial plasmids carrying a mammalian SV40 virus (originally specific to monkeys) to infect cultured mammalian cells, which then proceeded to synthesize the virus (87). Similarly, bacterial viruses and baculovirus (attacking insects) can also be taken up by mammalian cells $(88,150)$. One main route for the uptake of DNA by mammalian cells is by phagocytosis of bacteria containing the vector DNA. But baculovirus can gain access by itself. It is so good at getting into human liver cells that it is being engineered as a vector for gene replacement therapy (88, 


\section{Table IV}

Examples of vectors constructed for genetic manipulations

\begin{tabular}{|c|c|c|c|}
\hline Vectors & Sources & Host(s) & Uses \\
\hline \multicolumn{4}{|l|}{ Plasmid vectors } \\
\hline pBR322 & $\begin{array}{l}\left.\text { RSF2124 (Col E1, with transposon carrying } \mathrm{Ap}^{\mathrm{R}}\right) \\
\left.\text { pSC101 (with Tc }{ }^{\mathrm{R}}\right) \\
\text { pMB1 (Col E1-like) }\end{array}$ & E. coli & $\begin{array}{l}\text { Cloning and expressing genes of } \\
\text { all species in E. coli }\end{array}$ \\
\hline pBR322 shuttles & $\begin{array}{l}\text { pBR322 plus various plasmid/viral sequences } \\
\text { specific to other species }\end{array}$ & E. coli and others & Cloning and transfection \\
\hline \multirow[t]{2}{*}{ pHV14 } & $\mathrm{pBR} 322$ & E. coli and & Cloning in B. subtilis \\
\hline & pC194 (CmR plamid from S. aureus) & $\begin{array}{l}\text { B. subtilis } \\
\text { S. aureus? }\end{array}$ & \\
\hline YEp & E. coli plasmids and yeast plasmids & E. coli and yeast & Cloning and transfection \\
\hline YCp & E. coli plasmids and yeast centromeres & E. coli and yeast & Cloning and transformation \\
\hline YACs & E. coli plasmids and yeast telomeres & E. coli and yeast & $\begin{array}{l}\text { Cloning of large human genome } \\
\text { fragments }\end{array}$ \\
\hline \multirow{2}{*}{$\begin{array}{l}\text { Bin19 (used with } \\
\text { pAL4404) }\end{array}$} & pPK252 (Group P, with KanR) polylinker, & E. coli and others & Transformation of plants \\
\hline & $\begin{array}{l}\text { T-DNA of Agrobacterium Ti plasmid with neo } \\
\text { marker insert }\end{array}$ & & \\
\hline $\begin{array}{l}\text { pJP181 (used with } \\
\text { pAL4404) }\end{array}$ & pRSF1010 (Group Q, CmR) nео marker & E. coli and others & Transformation of plants \\
\hline \multirow[t]{4}{*}{ pRSV } & pBR322 & E. coli and others & Transgene expression in animals \\
\hline & SV40, bacterial neo or XGPRT marker or mouse & & \\
\hline & DHFR insert & & \\
\hline & Rous sarcoma virus promoter & & \\
\hline \multicolumn{4}{|l|}{ Phage vectors } \\
\hline$\lambda \mathrm{gt11}$ & $\lambda$ phage with $E$. coli lac & E. coli & Cloning and expression \\
\hline$\lambda$ gtWES.T5622 & $\lambda$ phage, phage $\mathrm{T} 5$ & E. coli & \\
\hline \multicolumn{4}{|l|}{ Cosmid vectors } \\
\hline $\mathrm{c} 2 \mathrm{XB}$ & $\begin{array}{l}\cos \text { fragment from } \lambda \text { phage } \\
\text { RSF2124 Ap }\end{array}$ & E. coli & Cloning \\
\hline \multicolumn{4}{|l|}{ Phasmid vectors } \\
\hline$\lambda \mathrm{ZAP}$ & Phages $\lambda, \mathrm{M} 13, \mathrm{~T} 3, \mathrm{~T} 7$, E. coli lac, RSF2124 $\mathrm{Ap}^{\mathrm{R}}$ & E. coli & $\begin{array}{l}\text { Cloning and expression, } \\
\text { restriction mapping sequencing }\end{array}$ \\
\hline \multicolumn{4}{|c|}{ Broad host range plasmid vectors } \\
\hline KT230 & RSF1010 (group Qm, SuR, SmR,) added KmR & E. coli and others & Cloning in other bacteria \\
\hline pRK203 & $\mathrm{RK} 2$ with $\mathrm{Km}^{\mathrm{R}}$ cloned into $\mathrm{Col} \mathrm{E} 1$ & E. coli and others & Mobilize plasmids into other hosts \\
\hline \multicolumn{4}{|c|}{ Broad host range transposon vectors } \\
\hline \multirow[t]{3}{*}{ pNJ5073 } & $\operatorname{Tn} 7$ (transposon with $\mathrm{Tp}^{\mathrm{R}}$ and $\mathrm{Sm}^{\mathrm{R}}$ ) & E. coli and others & Cloning in other bacteria \\
\hline & E. coli $\operatorname{trp} E$ & & \\
\hline & RK1 (plasmid with $\mathrm{Tc}^{\mathrm{R}}$ ) & & \\
\hline \multicolumn{4}{|l|}{ Plant viral vectors } \\
\hline $\mathrm{CaMV}$ & $\begin{array}{l}\text { gene } V I \text { and its strong } 35 \mathrm{~S} \text { promoter used rou- } \\
\text { tinely in vectors for plants }\end{array}$ & E. coli and others & Boost Transgene expression in plants \\
\hline \multicolumn{4}{|l|}{$\begin{array}{l}\text { Animal viral } \\
\text { vectors }\end{array}$} \\
\hline $\begin{array}{l}\text { Herpes simplex } \\
\text { virus }\end{array}$ & $\begin{array}{l}t k \text { gene incorporated into a range of vectors for } \\
\text { animal cells }\end{array}$ & $\begin{array}{l}\text { E. coli, humans, } \\
\text { others }\end{array}$ & Selectable marker \\
\hline SV40 & $\begin{array}{l}\text { hybrid vector with } E \text {. coli plasmid promoter and } \\
\text { enhancer genes in a range of vectors }\end{array}$ & $\begin{array}{l}\text { E. coli, monkey, } \\
\text { others }\end{array}$ & $\begin{array}{l}\text { Transformation and transgene expression } \\
\text { in animal cells }\end{array}$ \\
\hline Rous Sarcoma virus & $\begin{array}{l}\text { s promoter incorporated into a range of vectors for } \\
\text { animal cells }\end{array}$ & $\begin{array}{l}\text { E. coli, chicken, } \\
\text { others }\end{array}$ & Transgene expression in animal cells \\
\hline $\begin{array}{l}\text { Bovine papilloma } \\
\text { virus }\end{array}$ & hybrid vector with $E$. coli plasmid & $\begin{array}{l}\text { E. coli, bovine, } \\
\text { others }\end{array}$ & Transformation of animal cells \\
\hline MMTV & promoter incorporated into a range of vectors & E. coli, mouse & Expression \\
\hline Vaccinia virus & $\begin{array}{l}\text { many recombinant viruses with e.g. hepatitis, } \\
\text { AIDS, HTLV, rabies antigen gene }\end{array}$ & $\begin{array}{l}\text { E. coli, human, } \\
\text { others }\end{array}$ & Vaccines \\
\hline Baculovirus & $\begin{array}{l}\text { many recombinant viruses with toxins against } \\
\text { insects }\end{array}$ & E. coli, insects & Insecticidal \\
\hline & recombinant viruses with human genes & humans & Somatic gene therapy \\
\hline Adenovirus & recombinant viruses with human genes & E. coli, humans & Somatic gene therapy \\
\hline
\end{tabular}


Table IV

(Continued)

\begin{tabular}{|c|c|c|c|}
\hline Vectors & Sources & Host(s) & Uses \\
\hline Cytomegalovirus & promoter gene in a range of vectors & E. coli, humans & Transfection transformation \\
\hline $\begin{array}{l}\text { Retroviral vectors } \\
\text { MuLV }\end{array}$ & $\begin{array}{l}\text { hybrid vectors with } E \text {. coli plasmid neo markers } \\
\text { broadened host range hybrid vector }\end{array}$ & $\begin{array}{l}\text { E. coli, animals } \\
\text { E. coli, mammals, } \\
\quad \text { birds }\end{array}$ & Transformation and transgene expression \\
\hline \multicolumn{4}{|c|}{ Transposons as vectors and related uses } \\
\hline P element & $\begin{array}{l}\text { with polylinker } \\
\text { with } E \text {. coli ori } \\
\text { with } E \text {. coli lac } Z, A m p R\end{array}$ & $\begin{array}{l}\text { Drosophila } \\
\text { E. coli, Drosophila } \\
\text { E. coli, Drosophila }\end{array}$ & $\begin{array}{l}\text { Transformation } \\
\text { Mutagenesis } \\
\text { Enhancer trapping }\end{array}$ \\
\hline
\end{tabular}

150) at the same time that it is being engineered in agriculture to be a more effective insecticide, which should raise serious safety concerns (127). An important route for horizontal gene transfer from bacteria to mammalian cells may be conjugation. Bacterial conjugative plasmids can mobilize DNA transfer between bacteria and yeast (see Section 7.3). It was predicted that these plasmids raise the possibility that 'conjugation could occur between bacteria and animal cells and between bacteria and plant cells' ((71), p. 209). This prediction has been borne out. Recently, the prokaryote-eukaryote shuttle vectors pAT497 and pAT498 were both transferred from $E$. coli cells into mammalian cells by conjugation, with a helper plasmid from Shigella (151).

Once inside cells, the DNA may integrate at random into the host cell genome, causing correspondingly random genetic disturbances. Of particular concerns in this regard are vector DNA engineered with oncogenes (genes associated with cancer development) and other viral sequences which can cause cancers. Recombination between vector DNA and endogenous viruses can also generate new viral pathogens implicated in several types of animal cancers ((35), Chapter 13).

\section{4 'Crippled' laboratory strains of bacteria can survive in the environment}

There are a number of studies documenting the survival of 'crippled' laboratory strains of bacteria in the environment. E. coli $\mathrm{K} 12$ has been reisolated from lab coats after 20 days (152). Dott et al. (153) inoculated 6 different strains of GEMs into drinking water, surface water, sewage water and different kinds of soil. On introduction into the sewage under aerobic conditions, the GEMs died off quickly, but not under anaerobic conditions, where only one strain failed to survive the test period of 31 days. However, in sandy soil and nutrient rich garden soil, the GEM that survived least well in any kind of water had the longest life span.

Survival rates estimated by routine culture methods may be quite misleading. It is now well-known that all bacteria can survive starvation and undergo 'adaptive mutations' when presented with substrates that they cannot use ini- tially (see Section 5). Furthermore, bacteria can survive indefinitely in a non-proliferating, dormant form. This has been documented for a laboratory strain of E. coli K12, which when introduced into the sewage, went dormant and undetectable for 12 days before reappearing, having acquired a new plasmid for multidrug resistance that enabled it to compete with the naturally occurring bacteria (25). Dormant forms of bacteria and viruses can survive indefinitely as biofilms (see Section 5). In this state, the bacteria continue to accumulate new mutations, and to exchange genes, to come back with a vengeance, when the ecological conditions are ripe.

11.5 Direct documentation of the acquisition of antibiotic resistance, its spread by horizontal gene transfer and persistence

A study in Eastern Germany (25) gives an idea of the rapidity with which antibiotic resistance can develop and spread by horizontal gene transfer, and yet persist after the antibiotic ceased to be administered. The antibiotic streptothricin was administered to pigs beginning in 1982. By 1983, plasmids encoding streptothricin resistance was found in the pig gut bacteria. This has spread to the gut bacteria of farmworkers and their family members by 1984, and to the general public and pathological strains of bacteria the following year. The antibiotic was withdrawn in 1990. Yet the prevalence of the resistance plasmid has remained high when monitored in 1993, confirming the ability of microbial populations to serve as stable reservoirs for replication, recombination and horizontal gene transfer, in the absence of 'selective pressure'.

In a direct test of persistence of streptomycin-resistance (154), researchers cultured many independent lines of a streptomycin-resistant mutant of $E$. coli in the absence of the antibiotic. They found that all retained the resistance after 180 generations. Furthermore, the lines have, in the mean time, accumulated compensatory mutations in other parts of the genome which increased their competitive ability relative to the wild-type. Again, this demonstrates the irrelevance of conventional explanations of the 'natural selection of random mutations' with regard to the evolution of antibiotic resistance. 


\section{Chemical inactivation may be ineffective}

The above findings take on additional significance in the light of the recent report that the chemical treatment in waste-tanks of commercial aircrafts are insufficient to inactivate up to ten percent of viral and bacterial pathogens (39). Commercial-scale contained users of GEMs routinely release large amounts of wastes after chemical or physical 'inactivation'. How adequate are these inactivation measures? Even if inactivation is effective, we now know that the large amounts of recombinant DNA released can still be readily transferred to other bacteria by direct uptake (i.e. transformation). What is the current status of safety regulation in the light of all the recent findings?

\subsection{Safety regulations are grossly inadequate, and further relaxation is contemplated}

Novo Nordisk is a biotech company that prides itself on being environmentally conscious and transparent in its safety practices. Their 1996 Environmental Report (kindly sent to M.W.H. by the Environment Director) gives the following limits - set by the Danish authority - for untreated release of GEMs in terms of colony-forming units (roughly equivalent to live bacteria): waste water, 10000/ $\mathrm{ml}$, air $10000 / \mathrm{ml}$, solid waste, $10000 / \mathrm{g}$. These 'tolerated releases' have to be seen in the light of the minimum infective dose for E. coli $0157: \mathrm{H} 7$, which is less than 50 bacteria (4). The same company also recycles inactivated GEMs as fertilizers for crops, under the trade name NovoGro ${ }^{2}$.

Even if chemical inactivation methods are $100 \%$ effective, large amounts of recombinant DNA have already been, and continue to be routinely released into the environment in one form or another, either in the sewage or directly spread onto fields. Many kinds of dangerous recombinant DNA, containing pathogenic sequences, cancer-causing viruses, as well as antibiotic resistance genes can almost certainly transform bacteria in the environment and further recombine, spreading not only antibiotic and virulence genes in bacteria, but also generating new viral pathogens.

There is an urgent need to re-assess the safety regulation, not only of deliberate releases, but also of contained use. Instead of which, our regulators are contemplating further relaxations.

The UK Health and Safety Executive (HSE) has drafted a document, circulated for consultation in June 1997, which would allow commercial and other contained users to release certain classes of live GEMs as liquid wastes into the environment, without dilution or chemical inactivation $^{3}$. In September the same year, the US Environmental Protection Agency (EPA) has authorized a biotech company to sell $500000 \mathrm{lb}$ of a genetically engineered Rhizobium melitoti strain, for coating alfalfa seeds before planting. The GE Rhizobium 'contains an extra copy of the gene controlling nitrogenase production, genes to increase internal energy production, a gene conferring resistance to the antibiotics streptomycin and spectinomycin, and some uncharacterized $\mathrm{DNA}^{4}$. The antibiotics are currently used in treating $\mathrm{TB}$, the top killer in the world to-day. This news item was put out by one of the EPA's own officials, who has been protesting on the internet against the agency's effective lack of biosafety oversight on genetically engineered products.

\section{CONCLUSION}

In this paper, we have reviewed a variety of evidence-inductive, deductive and circumstantial-linking genetic engineering biotechnology to the recent resurgence in infectious diseases. A summary of the evidence is presented below.

Possible links between genetic engineering biotechnology and the recent resurgence of infectious diseases

\section{Inductive}

1. Horizontal gene transfer (and consequent recombination) is found to be responsible for the spread of virulence and antibiotic resistance.

2. Direct experimental evidence of horizontal gene transfer, some between phylogenetically distant species, has been obtained in all natural environments as well as in the gastrointestinal tract. These were all accomplished using artificially constructed vectors.

3. Genetic engineering biotechnology makes extensive use of antibiotic resistance genes as selectable markers, thereby increasing the spread of antibiotic resistance genes.

4. The presence of antibiotics increases the frequency of horizontal gene transfer 10 to 10000 -fold, thereby encouraging the horizontal transfer and recombination of virulence as well as antibiotic resistance genes. 'Crippled' strains of bacteria can survive in the environment to exchange genes with bacteria in the environment.

5. DNA released from dead cells (as well as live cells) are not readily broken down in the general environment, nor in the gastroinstestinal tract, where they may retain the ability to transform other bacteria.

6. Some viral DNA is more infectious than the virus itself.

7. Routine chemical inactivation of geneticially engineered microorganisms prior to disposal in the general environment may be ineffective, leaving a substantial proportion of viruses and bacteria in an infective state.

8. Current legal limits of 'tolerated releases' of GEMs from contained use vastly exceed the minimal infective dose of pathogens and potential pathogens. 
9. Non-pathogens are transformed into pathogens by horizontal gene transfer of unit blocks of virulence genes.

10. Horizontal gene transfers are bi-directional. Released non-pathogens can be readily converted into pathogens in one step, by acquiring unit-blocks of virulence genes.

\section{Deductive}

1. Genetic engineering is based on facilitating horizontal gene transfer between distant species by constructing vectors that break down species barriers.

2. The artificial vectors constructed for genetic engineering are chimaeric combinations of viral pathogens and other invasive genetic elements that can generate new cross-species viral pathogens.

3. The artificial vectors constructed for genetic engineering are inherently unstable and prone to recombination, thereby enhancing horizontal gene transfer and recombination.

4. Shuttle vectors made by genetic engineering are essentially unstoppable, as they contain signals for transfer and replication in different species; and helper functions for mobilization and transfer can be supplied by viruses, plasmids and transposons which occur naturally in bacteria in all environments.

\section{Circumstantial}

1. The accelerated emergence of infectious diseases and of drug and antibiotic resistance coincide with the development of commercial genetic engineering biotechnology.

2. Many horizontal gene transfer events responsible for the spread of virulence and antibiotic resistance are recent, based on the high degree ( $>99 \%$ ) of homologies in sequences of genes found in unrelated species.

The totality of evidence is sufficiently compelling, especially in view of the precautionary principle, to warrant, at the very least, an independent, full public enquiry into genetic engineering biotechnology and the etiology of infectious diseases. In addition, we urgently need research directed at understanding general mechanisms for horizontal gene transfer, which aim to strengthen the barriers against the transfer of recombinant DNA, and which can form the basis for scientific risk assessment. Such research must be carried out by independent research groups dedicated to the task, and not left in the hands of those who are involved in commercial exploitation of genetic engineering biotechnology.

\section{NOTES}

1. The UK Health and Safety Executive, on the recommendation of the Advisory Committee on Genetic
Modification (ACGM), produced a consultation document, Draft Guidance on Certificate of Exemption No. 1 , which would allow commercial and other contained users to release certain classes of live GEMs directly into the environment as liquid wastes on notification, without the need to monitor for the survival and subsequent evolution of the GEMs.

2. M.W.H. wrote to Lise Kingo, Novo Nordisk's Director of Environment on 30 June, 1997, expressing her reservations on existing practice and regulations on contained use, requesting more information on their monitoring of released GEMs and whether it included monitoring for horizontal gene transfer. Kingo replied by e-mail two weeks later, stating that their scientists were on holiday. M.W.H. raised the matter again, during the UN Biosafety meeting in Montreal in October 1997, with Mr. J.L. Mahler, Novo Nordisk's Vice President of External Affairs, who also attended the meeting. Mr. Mahler agreed to remind their scientists to send a reply. This came from Lise Kingo more than two months later, stating that horizontal gene transfer is nothing new. 'It is a well known and naturally occurring phenomenon which was taken into account by legislators both when the present contained use directive was written and when its current revision was proposed.' Therefore, they saw no need to review existing practice and regulations. Again, they failed to answer M.H.W.'s questions on monitoring for GEM survival and for horizontal gene transfer.

3. The consultation document, Draft Guidance on Certificate of Exemption No. 1, was not widely circulated even within the genetic engineering community. After several exchanges of correspondence between M.W.H. and members of parliament, the Health and Safety Executive has agreed, in a letter dated 10 October, 1997, that 'some important issues' were raised, which were to be discussed by the Technical Sub-Committee (TSC) of the Advisory Committee for Genetic Manipulation. The result of the deliberation was communicated to M.W.H. in a letter dated 17 December, which stated, 'The Committee felt that some of the issues that had been raised went wider than just the hazards associated with any possible discharge of Group 1 GMMS and there were implications for the disposal of both inactivated and non-inactivated waste.

'While the issues you raised are not new, we agree that they are important. We believe that most aspects are already covered sufficiently in the current guidance, however, some of the issues discussed perhaps warrant further attention as part of our continuing programme of update in the light of scientific evidence. HSE has decided therefore to commission an independent, thorough and critical review of the literature, in particular focusing on any new data available on the hazards 
which may be associated with gene transfer from GMMs in the environment and the hazards associated with free DNA released by such micro-organisms...' However, we doubt that further literature review is sufficient. We need targetted experimental research on horizontal gene transfer, and DNA sequence comparisons between, say, pathogenicity islands and phage and phasmid vectors, for example.4. 'First commercial release of microorganism under TSCA' E-mail message from Suzanne Wuerthele, 22 September, 1997.

$<$ Wuerthele.Suzanne@epamail.epa.gov >

\section{REFERENCES}

1. WHO Report. World Health Organization, Geneva, 1996.

2. Lederberg J. Infectious disease as an evolutionary paradigm. Emerging Infectious Diseases 1997; 3: < http://www.cdc. gov/ncidod/EID/eid.htm >

3. WHO Fact Sheet No. 139, January 1997.

4. Smith HR. Vero cytotoxin-producing Escherichia coli 0157: cause for concern. SGM Quarterly 1997; May: 54-5.

5. Elegant S. Poor man's plague. Far Eastern Economic Review 1997; April 17: 42-5.

6. Garrett L. The coming plague. New York: Penguin Books, 1995.

7. Neu HC. The crisis in antibiotic resistance. Science 1992; 237: 1064-72.

8. Udo EE, Grubb WB. Transfer of resistance determinants from a multi-resistant Staphylococcus aureus isolate. J Med Microbiol 1990; 35: 72-9.

9. Brown DFJ, Farrington M, Warren RE. Imipene-resistant Escherichia coli. Lancet 1993; 342: 177.

10. Day M. Superbug spectre haunts Japan. New Sci 1997; 3: 5.

11. Zepelin J. US-Gesellschaft fuer Infektionskrankheiten warnt vor Ausbreitung resistenter Krankheitserreger/Bessere Hygiene. Reporting on the annual conference of the Infectious Diseases Society of America (IDSA) in Frankfurter Rundschau, 1997; October 12.

12. Cornaglia G, Ligozzi M, Mazzariol A, Valentini M, Orefici G, Fontana R. Rapid increase of resistance to erythromycin and clindamycin in Streptococcus pyogenes in Italy, 19931995. Emerging Infectious Diseases, 1996; 2: < http:/ www.cdc.gov/ncidod/EID/eid.htm >

13. Ho MW. Are current transgenic technologies safe? Capacity building in biosafety urgently needed for developed countries. In: Virgin I, Frederick RJ, eds. Biosafety capacity building: evaluation criteria development. Stockholm: Stockholm Environment Institute, 1996: 75-80.

14. Ho MW, Tappeser B. Potential contributions of horizontal gene transfer to the transboundary movement of living modified organisms resulting from modern biotechnology. In: Mulongoy KJ, ed. Proceedings of Workshop on Transboundary Movement of Living Modified Organisms Resulting from Modern Biotechnology: Issues and Opportunities for Policy-makers. Geneva: International Academy of the Environment, 1997: 171-93.

15. Bik EM, Bunschoten AE, Gouw RD, Mooi FR. Genesis of novel epidemic vibrio-cholerae-0139 strain-evidence for horizontal transfer of genes involved in polysaccharide synthesis. EMBO 1995; 14: 209-16.

16. Prager R, Beer W, Voigt W, et al. Genomic and biochemical relatedness between vibrio-cholerae. Microbiol Virol Parasitol Infect Dis 1995; 283: 14-28.
17. Reidl J, Mekalanos JJ. Characterization of Vibrio-cholerae bacteriophage-K139 and use of a novel mini-transposon to identify a phage-encoded virulence factor. Mol Microbiol 1995; 18: 685-701.

18. Whatmore AM, Kehoe MA. Horizontal gene-transfer in the evolution of group-A Streptococcal emm-like genes-gene mosaics and variation in vir regulons. Mol Microbiol 1994; 11: $363-74$.

19. Kapur V, Kanjilal S, Hamrick MR, et al. Molecular population genetic-analysis of the streptokinase gene of Streptococcus-pyogenes - mosaic alleles generated by recombination. Mol Microbiol 1995; 16: 509-19.

20. Schnitzler N, Podbielski A, Baumgarten G, Mignon M, Kaufhold A. M-protein or M-like protein gene polymorphisms in human group-G Streptococci. J Clin Microbiol 1995; 33: 356-63.

21. Upton M, Carter PE, Organe G, Pennington TH. Genetic heterogeneity of M-type-3 G group-A Streptococci causing severe infections in Tayside, Scotland. J Clin Microbiol 1996; 34: $196-8$.

22. Pennington H. BBC Radio 4 Today Programme, Feb. 1997; confirmed by personal communication, 1997.

23. Barinaga M. A shared strategy for virulence. Science 1996; 272: $1261-3$

24. Davies J. Inactivation of antibiotics and the dissemination of resistance genes. Science 1994; 264: 375-82.

25. Tschäpe $H$. The spread of plasmids as a function of bacterial adaptability. FEMS Microbiol Ecol 1994; 15: 23-32.

26. Miller PR, Sulavik MC. Overlaps and parallels in the regulation of intrinsic multiple-antibiotic resistance in Escherichia coli. Mol Microbiol 1996; 21: 441-8.

27. Mazodier P, Davies J. Gene transfer between distantly related bacteria. Ann Rev Gen 1991; 25: 147-71.

28. Salyers AA, Shoemaker NB, Li LY. In the driver's seat: the Bacteroides conjugative transposons and the elements they mobilize. J Bacteriol 1995; 177: 5727-31.

29. Torres OG, Korman RZ, Zahler SA, Dunny GM. The conjugative transposon Tn925: enhancement of conjugal transfer by tetracycline in Enterococcus faecalis and mobilization of chromosomal genes in Bacillus subtilis and E. faecalis. Mol Gen Genet 1991; 225: 395-400.

30. Sandaa RA, Enger $\varnothing$. Transfer in marine sediments of the naturally occurring plasmid pRAS1 encoding multiple antibiotic resistance. Appl Environ Microbiol 1994; 60: $4243-$ 8.

31. Cohen ML. Epidemiology of drug resistance: implications for a post-antimicrobial era. Science 1992; 257: 1050-5.

32. Report of the ASM Task Force on Antibiotic Resistance, American Society for Microbiology, 1995.

33. Mahy BWJ. Emerging virus infections. Viral Immunol 1997; 48: $1-2$.

34. Jager MJ, Tappeser B. Risk assessment and scientific knowledge. Current data relating to the survival of GMOs and the persistence of their nucleic acids: Is a new debate on safeguards in genetic engineering required?-considerations from an ecological point of view. Preprint circulated and presented at the TWN-Workshop on Biosafety, April 10, New York, 1995. A shortened version, Politics and science in risk Assessment. In: van Dommelen A, ed. Coping with deliberate release. The Limits of Risk Assessment, Tilburg: International Centre for Human and Public Affairs 1996: $63-72$.

35. Ho MW. Genetic engineering dream or nightmare-The brave new world of bad science and big business. Third World Network, Penang, Malaysia, and Gateway Books, Bath, 1997. 
36. Traavik T. Too Early May Be Too Late. Ecological Risks Associated with the Use of Naked DNA as a Biological Tool for Research, Production and Therapy (Norwegian), Report for the Directorate for nature Research Tungasletta 2, 7005 Trondheim, 1995. English translation, 1998.

37. Lorenz MG, Wackernagel W. Bacterial gene transfer by natural genetic transformation in the environment. Microbiol Rev 1994; 58: 563-602.

38. Yin X, Stotzky G. Gene transfer among bacteria in natural environment. Appl Microbiol 1997 (in press). (Preprint kindly supplied by the author, S.G.)

39. Coghlan A. Jetsetters send festering faeces round the world. New Scientist 1997; 17: 7.

40. Old RW, Primrose SB. Principles of gene manipulation, 5th ed. Oxford: Blackwell Science, 1994.

41. Riley LW, Remis RS, Helgerson SD, et al. Hemorrhagic colitis associated with a rare Escherichia coli Serotype. N Engl J Med 1983; 308: 681-5.

42. Khor M. Drug-resistant germs cause alarm. The Star 1997; 30: 18 .

43. Swinbanks D. Japan shuns radishes after 'possible link' to $E$. coli. Nature 1996; 382: 567.

44. Knight P. Hemorrhagic E. coli: The danger increases. ASM News 1993; 59: 247-50.

45. Mackey BM, Gibson GR. Escherichia coli 0157: From farm to fork and beyond. SGM Quarterly 1998; May : 55-7.

46. Volk WA, Gerbhardt BM, Hammarskjold ML, Kadner RJ. Essentials of medical microbiology, 5th ed. Philadelphia: Lippincott-Raven Publishers, 1995.

47. Nikaido H. Prevention of drug access to bacterial targets: permeability barriers and active efflux. Science 1994; 264: $382-8$.

48. Spratt BG. Resistance to antibiotics mediated by target alterations. Science 1994; 264: 388-93.

49. Smirnov VV, Rudendo AV, Samgorodskaya NV, et al. Susceptibility to antimicrobials drugs of Baccilli used as basis for some probiotics. Antibiot-Khimiorec 1994; 39: $23-8$.

50. Coghlan A. That's us stuffed then. New Scientist 1997; 6 December: p. 5.

51. Bostock CJ, Tyler-Smith C. Changes to genomic DNA in methotrexate-resistant cells. In: Dover GA, Flavell RB, eds. Genome evolution. London: Academic Press, 1982: 69-94.

52. Gudkov A, Kopnin B. Gene amplification in multidrug-resistant cells: molecular and karyotypic events. BioEssays 1985; 3: 68-71.

53. Hyrien $\mathrm{O}$, Buttin G. Gene amplification in pesticide-resistant insects. Trends Genet 1986; 2: 275-6.

54. DiFronzo NL, Holland CA. A direct demonstration of recombination between an injected virus and endogenous viral sequences, resulting in the generation of mink cell focus-inducing viruses in AKR mice. J Virol 1993; 67: 3763 70.

55. Foster PL. Directed mutation: between unicorns and goats. J Bacteriol 1992; 174: 1711-6.

56. Symonds N. Directed mutation: a current perspective. J Theor Biol 1994; 169: 317-22.

57. Ho MW. Why Lamarck won't go away. Ann Hum Genet 1996; 60: 81-4.

58. Ho MW. Evolution by process, not by consequence: implications of the new molecular genetics for development and evolution. Int J Comp Psychol 1987; 1: 3-27.

59. Shapiro J. Genome organization, natural genetic engineering and adaptive mutation. TIG 1997; 13: 98-104.

60. Lewis DL, Gattie DK. The ecology of quiescent microbes. ASM News 1991; 57: 27-32.
61. Costerton JW, Lewandowski Z, DeBeer D, et al. Biofilms, the customized microniche. J Bacteriol 1994; 176: 2137-42.

62. The Harvard Working Group on New and Resurgent Diseases. New and resurgent diseases. The failure of attempted eradication. The Ecologist 1995; 25: 21-6.

63. Levy SB, Novick R, eds. Antibiotic resistance genes: ecology, transfer, and expression, 24 Banbury Report, New York: Cold Spring Harbour Laboratory, 1986.

64. Trieu-Cuot P, Gerbaud G, Lambert T, Courvalin P. In vivo transfer of genetic information between Gram-positive and Gram-negative bacteria. EMBO J 1985; 4: 3583-7.

65. Sougakoff N, Papadopoulou B, Norman P, Courvalin P. Nucleotide sequence and distribution of gene tet $O$ encoding tetracycline resistance in Campylobacter coli. FEMS Microbiol Lett 1987; 44: 153-9.

66. Manavathu EK, Hiratsuka K, Taylor DE. Nucleotide sequence analysis and expression of a tetracycline resistance gene from Campylobcter jejuni. Gene 1988; 62: 17-26.

67. Kell CM, Hordens JZ, Daniels M, et al. Molecular epidemiology of penicillin-resistant pneumococci isolated in Nairobi, Kenya. Infect Immun 1993; 61: 4382-91.

68. Amabilecuevas CF, Chicurel ME. Horizontal gene transfer. American Science 1993; 81: 332-41.

69. Coffey TJ, Dowson CG, Daniels M, Spratt BG. Genetics and molecular-biology of $\beta$-lactam-resistant pneumococci. Microb Drug Resist-Mech Epidemiol Dis 1995; 1: 29-34.

70. Bootsma JH, Vandijk H, Verhoef J, Fleer A, Mooi FR. Molecular characterization of the bro $\beta$-lactamase of moraxella (Branhamella) catarrhalis. Antimicrob Agents Chemother 1996; 40: 966-72.

71. Heinemanne JA, Sprague GR, Jr. Bacterial conjugative plasmids mobilize DNA transfer between bacteria and yeast. Nature 1989; 340: 205-9.

72. Sikorski RS, Michaud W, Levin HL, Boeke JD, Hieter P. Trans-kingdom promiscuity. Nature 1990; 345: 581-2.

73. Schäfer A, Kalinowski J, Simon R, Seep-Feldhaus AH, Pühler A. High-frequency conjugal plasmid transfer from gram-negative Eschericia coli to various gram-positive bacteria. J Bacteriol 1990; 172: 1663-6.

74. Nishikawa M, Katsunori S, Yoshida D. DNA integration into recipient yeast chromosomes by trans-kingdom conjugation between Escherichia coli and Saccharomyces cerevesiae. Curr Genet 1992; 21: 101-8.

75. Stephenson JR, Warnes A. Release of genetically-modified microorganisms into the environment. J Chem Tech Biotech 1995; 65: 5-16.

76. Harding $\mathrm{K}$. The potential for horizontal gene transfer within the environment. Agro-Food-Industry Hi-Tech 1996: July/ August: $31-5$.

77. Krishnapillai V. Horizontal gene transfer. J Genet 1996; 75 : 219-32.

78. Cohen P. Doctor, there's a fly in my genome. New Scientist 1996; March 9: 6.

79. Stachel SC, Timmerman B, Zambryski P. Generation of single-stranded T-DNA molecules during the initial stages of T-DNA transfer from Agrobacterium tumefaciens to plant cells. Nature 1986; 322: 706-12.

80. Kado CI. Agrobacterium-mediated transfer and stable incorporation of foreign genes in plants. In: Clewell DB, ed. Bacterial conjugation. New York: Plenum Press, 1993: 24354.

81. Sikorski RS, Hieter P. A system of shuttle vectors and yeast host strains designed for efficient manipulation of DNA in Saccharomyces cerevisiae. Genetics 1989; 122: 19-27.

82. Buchanan-Wollaston V, Passiatore JE, Cannon F. The mob and oriT mobilization functions of a bacterial plasmid promote its transfer to plants. Nature 1987; 328: 172-5. 
83. Hoffman T, Golz C, Schieder O. Foreign DNA sequences are received by a wild-type strain of Aspergillus niger after co-culture with transgenic higher plants. Curr Genet 1994; 27: $70-6$.

84. Schluter K, Futterer J, Potrykus I. Horizontal gene-transfer from a transgenic potato line to a bacterial pathogen $(\mathrm{Er}$ winia-chrysanthem) occurs, if at all, at an extremely low-frequency. BioTechnology 1995; 13: 1094-8.

85. Smalla K. Personal communication, 1997.

86. Wackernagel W. Personal communication, 1997.

87. Heitmann D, Lopes-Pila JM. Frequency and conditions of spontaneous plasmid transfer from E. coli to cultured mammalian cells. Biosystems 1993; 29: 37-48.

88. Hofmann C, Sandig V, Jennings G, Rudolph M, Schlag P, Stauss M. Efficient gene transfer into human hepatocytes by baculovirus vectors. Proc Natl Acad Sci USA 1995; 92: 10099-103.

89. Kendrew J, editor. The encyclopedia of molecular biology, Oxford: Blackwell Science, 1995.

90. Woese CR. Bacterial evolution. Microbiol Rev 1987; 51: 221-71.

91. Pace N. A molecular view of microbial diversity and the biosphere. Science 1997; 276: 734-9.

92. Strauss EJ, Falkow S. Microbial pathogenesis: genomics and beyond. Science 1997; 276: 707-12.

93. Daane LL, Molina JAE, Sadowsky MJ. Plasmid transfer between spatially separated donor and recipient bacteria in earthworm-containing soil microcosms. Appl Environ Microbiol 1997; 63: 679-86.

94. Fredericksen K. Anti-native DNA antibodies induced by BK virus and BK virus native DNA. Ph. D. thesis, Department of Virology, Institute of Medical Biology, University of Tromso, 1993.

95. Cohen J. Naked DNA points way to vaccines. Science 1993; 259: $1691-2$.

96. Sandmeier H. Acquisition and rearrangement of sequence motifs in the evolution of bacteriophage tail fibres. Mol Microbiol 1994; 12: 343-50.

97. Bergh O, Borsheim KY, Bratbak G, Heldal M. High abundance of viruses found in aquatic environments. Nature 1989; 340: $467-8$.

98. Miller RV. Bacterial gene swapping in nature. Sci Am 1998; Jan.: $67-71$

99. Ippen-Ihler K, Skurray RA. Genetic organization of transferrelated determinants on the sex factor $\mathrm{F}$ and related plasmids. In: Clewell DB, ed. Bacterial Conjugation. New York: Plenum Press, 1993: 23-52.

100. Clewell DB, ed. Bacterial conjugation, New York: Plenum Press, 1993.

101. Franke AE, Clewell DB. Evidence for a chromosome-borne resistance transposon ( $\operatorname{Tn} 916)$ in Streptococcus faecalis that is capable of 'conjugal' transfer in the absence of a conjugative plasmid. J Bacteriol 1981; 145: 494-502.

102. Clewell DB, Flannagan SE. The conjugative transposons of gram-positive bacteria. In: Clewell DB, ed. Bacterial conjugation. New York: Plenum Press, 1993: 369-93.

103. Stokes HW, Hall RM. A novel family of potentially mobile DNA elements encoding site-specific gene-integration functions: integrons. Mol Microbiol 1989; 3: 1669-83.

104. Stokes HW, Hall RM. The integron in plasmid R46 includes two copies of the oxa2 gene cassette. Plasmid 1992; 28: $225-34$.

105. Collis CM, Grammaticopoulous G, Briton J, Stokes HW, Hall RM. Site-specific insertion of gene cassettes into integrons. Mol Microbiol 1993; 9: 41-52.
106. Kipling D, Kearsey SE. Reversion of autonomously replicating sequence mutations in Saccharomyces cerevisiae: creation of a eucaryotic replication origin with procaryotic vector DNA. Mol Cell Biol 1990; 10: 265-72.

107. Howard V. Synergistic effects of chemical mixtures. Can we rely on traditional toxicology. The Ecologist 1997; 27: 193 5.

108. Roberts MC. Gene transfer in the urogenital and respiratory tract. In: Levy S, Miller RV, eds. Gene transfer in the environment. New York: McGraw-Hill Book Co, 1989: 347-75.

109. Roberts MC, Hillier SL. Genetic basis of tetracycline resistance in urogenital bacteria. Antimicrob Agents Chemother 1990; 34: 261-4.

110. Speer BS, Shoemaker NB, Salyers AA. Bacterial resistance to tetracyclne: mechanisms, transfer and clinical significance. Rev Microbiol 1992; 5: 387-99.

111. Pang Y, Brown BA, Steingrube VA, Wallance RJ, Jr. Roberts MC. Tetracycline resistance determinants in $\mathrm{Myco}$ baterium and Streptomyces species. Antimicrob Agents Chemother 1994; 38: 1408-12.

112. Spratt BG. Hybrid penicillin-binding proteins in penicillinresistant strains of Neisseria gonorrhoeae. Nature 1988; 332: $173-6$.

113. Kehoe MA, Kapur V, Whatmore A, Musser JM. Horizontal gene transfer among group A streptococci: implications for pathogenesis and epidemiology. Trends Microbiol 1996; 4: 436-43.

114. Reddy SP, Rasmussen WG, Baseman JB. Molecular-cloning and characterization of an adherence-related operon of myocplasma-genitalium. J Bacteriol 1995; 177: 5943-51.

115. Finlay BB, Cossart P. Exploitation of mammalian host cell functions by bacterial pathogens. Science 1997; 276: 718-25.

116. Salyers AA, Whitt DD. Bacterial Pathogenesis: a molecular approach. Washington, DC: American Society for Microbiology Press, 1994.

117. Waldo MK, Mekalanos JJ. Lysogenic conversion by a filamentous phage encoding cholera toxin. Science 1996; 272: 1910-4.

118. Hacker J, Blum-Oehler G, Muhldorfer I, Tschäpe H. Pathogenicity islands of virulent bacteria: structure, function and impact on microbial evolution. Mol Microbiol 1997; 23: 1089-97.

119. McDaniel TK, Keper JB. A cloned pathogenicity island from enteropathogenic Escherichia coli confers the attaching and effacing phenotype of E. coli K12. Mol Biol 1997; 23: 399-467.

120. Baker B, Zambryski P, Staskawicz B, Dinesh-Kumar SP. Signalling in plant-microbe interactions. Science 1997; 276: 726-33.

121. Hughes VM, Datta N. Conjugative plasmids in bacteria of the 'pre-antibiotic' era. Nature 1983; 302: 725-6.

122. Barcus VA, Titheradge AJB, Murray NE. The diversity of alleles at the hsd locus in natural populations of Escherichia coli. Genetics 1995; 140: 1187-97.

123. Naito T, Kusano K, Kobayashi I. Selfish behaviour of restriction-modification systems. Science 1995; 267: 897-9.

124. Saunders JR, Saunders VA. Genotypic and phenotypic methods for the detection of specific released micro-organisms. In: Edwards E, ed. Monitoring genetically manipulated micro-organisms in the environment. New York: John Wiley \& Sons, 1993: 27-59.

125. Schäfer A, Kalinowski J, Pühler A. Increased fertility of Corynebacterium glutamicum recipients in intergeneric matings with Escherichia coli after stress exposure. Appl Environ Microbiol 1994; 60: 756-9. 
126. Atlas M, Bennett AM, Colwell R, et al. Persistence and survival of genetically-modified micro-organisms released into the environment. In: Stewart-Rull DES, Sussman M, eds. The release of genetically modified microorganisms. New York: Plenum Press, 1992.

127. Ho MW, Steinbrecher RA. Fatal Flaws in Food Safety Assessment. A Critique of the Joint FAO/WHO Biotechnology and Food Safety Report. Penang: Third World Network, 1997.

128. Höfle MG. Auswirkungen der Freisetzung backerieller Monokulturen auf die naturliche Midroflora aquatischer Okosysteme. In Biologische Sicherheit/Forschung Biotechnologie BMFT 1994; 3: 795-820.

129. Moens L, Vanfleteren J, Vandepeer Y, et al. Globins in nonvertebrate species-dispersal by horizontal gene transfer and evolution of the structure-function relationships. Mol Biol Evol 1996; 13: 324-33.

130. Mazodier P, Petter R, Thompson C. Intergeneric conjugation between Escherichia coli and Streptomyces species. J Bacteriol 1989; 171: 3583-5.

131. Frischer ME, Stewart GJ, Paul JH. Plasmid transfer to indigenous marine bacterial-populations. FEMS Microbiol Ecol 1994; 15: 127-35.

132. Lebaron Ph, Batailler N, Baleux B. Mobilization of a recombinant nonconjugative plasmid at the interface between wastewater and the marine coastal environment. FEMS Microbiol Ecol 1994; 15: 61-70.

133. Ripp S, Ogunseitan OA, Miller RV. Transduction of a fresh-water microbial community by a new Pseudomonasaeruginosa generalized transducing phage, UTI. Mol Ecol 1994; 3: 121-6.

134. Neilson JW, Josephson KL, Pepper IL, et al. Frequency of horizontal gene-transfer of a large catabolic plasmid (PJP4) in soil. Appl Environ Microbiol 1994; 60: 4053-8.

135. Goodman AE, Marshall KC, Hermansson M. Gene transfer among bacteria under conditions of nutrient depletion in simulated and natural aquatic environments. FEMS Microbiol Ecol 1994; 15: 55-60.

136. Mezrioui N, Echab K. Drug resistance in Salmonella strains isolated from domestic wastewater before and after treatment in stabilization ponds in an arid region (Marrakech, Morocco). World J Microbiol Biotechnol 1995; 11: 287-90.

137. Doucet-Populaire F. Conjugal transfer of genetic information in gnotobiotic mice. In: Gauthier MJ, ed. Microbial releases. Berlin: Springer Verlag, 1992.

138. Guillot JF, Boucaud JL. In vivo transfer of a conjugative plasmid between isogenic Escherichia coli strains in the gut of chickens in the presence and absence of selective pressure. In: Gauthier MJ, ed. Microbial releases. Berlin: Springer Verlag, 1992: 167-74.

139. Anderson ES. Viability of, and transfer of a plasmid from E. coli K12 in the human intestine. Nature 1975; 255: 502.

140. Freter R. The need for mathematical models in understand- ing colonization; and plasmid transfers in the mammalian intestine. In: Clewell DB, ed. Bacterial Conjugation. New York: Plenum Press, 1986: 81-93.

141. Roberts MC. Gene transfer in the urogenital and respiratory tract. In: Levy S, Miller RV, eds. Gene transfer in the environment. New York: McGraw-Hill Book Co, 1989: $347-75$.

142. Stephenson JR, Warnes A. Release of genetically-modified microorganisms into the environment. J Chem Tech Biotech 1996; 65: 5-16.

143. Harding $\mathrm{K}$. The potential for horizontal gene transfer within the environment. Agro-Food-Industry Hi-Tech 1996: July/ August: $31-5$.

144. Berg P, et al. Potential biohazards of recombinant DNA molecules. Science 1974; 185: 303.

145. Heitkamp MA, Kane JF, Morris PJL, et al. Fate in sewage of a recombinant Escherichia coli $\mathrm{K} 12$ strain used in the commercial production of bovine somatotropin. J Indust Microbiol 1993; 11: 243-52.

146. Crecchio C, Stotzky G. Binding of DNA from Bacillus subtilis on soil humic acids: implications for bacterial transformation in soil. Abst. 8th Meeting. International Humic Substances Society, 1996.

147. Schubbert R, Lettmann C, Doerfler W. Ingested foreign (phage M13) DNA survives transiently in the gastrointestinal tract and enters the bloodstream of mice. Mol Gen Genet 1994; 242: 495-504.

148. Schubbert R, Renz D, Schmitz B, Doerfler W. Foreign (M13) DNA ingested by mice reaches peripheral leukocytes, spleen and liver via the intestinal wall mucosa and can be covalently linked to mouse DNA. Proc Natl Acad Sci USA 1997; 94: 961-6.

149. Cohen P. Can DNA in food find its way into cells? New Scientist 1997; January 4: 14.

150. Sandig V, Hofmann C, Steinert S, et al. Gene transfer into hypatocytes and human liver tissue by baculovirus vectors. Hum Gene Ther 1996; 7: 1937-45.

151. Goussard S, Grillot-Courvalin C, Courvalin P. Direct gene transfer from bacteria to mammalian cells by kamikazation. 96th General Meeting of the American Society of Microbiology 1996: H-84: 497.

152. Cremers HCJ, Groot HF, Survival of E. coli K12 on laboratory coats made of $100 \%$ cotton. Bilthoven: Rijksinstituut voor Voldsgezondheid en Milieuhygiëne. Report No. $719102009,1991$.

153. Dott W, Khoury N, Ankel-Fuchs D, Henninger W, Kämpfer P. Überlebensfähigkeit von genetisch veränderten Escherichia coli- Stämmen. 2. Mitteilung: Überleben von Reinkulturen in versichiedenen Wasser- und Bodenmatrices. Zentralblatt Hygiene 1991; 192: 1-13.

154. Schrag SJ, Perrot V. Reducing antibiotic resistance. Nature 1996; 381: 120-1. 